\title{
Diversity and functional traits of lichens in ultramafic areas: a literature- based worldwide analysis integrated by field data at the regional scale
}

\begin{abstract}
While higher plant communities found on ultramafics are known to display peculiar characteristics, the distinguishability of any peculiarity in lichen communities is still a matter of contention. Other biotic or abiotic factors, rather than substrate chemistry, may contribute to differences in species composition reported for lichens on adjacent ultramafic and non-ultramafic areas. This work examines the lichen biota of ultramafics, at global and regional scales, with reference to species-specific functional traits. An updated world list of lichens on ultramafic substrates was analyzed to verify potential relationships between diversity and functional traits of lichens in different Koppen-Geiger climate zones. Moreover, a survey of diversity and functional traits in saxicolous communities on ultramafic and non-ultramafic substrates was conducted in Valle d'Aosta (North-West Italy) to verify whether a relationship can be detected between substrate and functional traits that cannot be explained by other environmental factors related to altitude. Analyses (un-
\end{abstract}

S. E. Favero-Longo $(\bowtie) \cdot$ E. Matteucci

Dipartimento di Scienze della Vita e Biologia dei Sistemi, Università degli Studi di Torino, Viale Mattioli 25 ,

10125 Turin, Italy

E-mail: sergio.favero@unito.it

Tel.: +390116705972

P. Giordani

Dipartimento di Farmacia, Università di Genova, Viale Cembrano

4, 16148 Genoa, Italy

A. G. Paukov

Department of Biodiversity and Bioecology, Institute of Natural

Sciences, Ural Federal University, 620000 Ekaterinburg, Russia

N. Rajakaruna

Biological Sciences Department, California Polytechnic State

University, San Luis Obispo, CA 93407, USA

N. Rajakaruna

Unit for Environmental Sciences and Management, North-West University, Private Bag X6001, Potchefstroom 2520, South Africa weighted pair group mean average clustering, canonical correspondence analysis, similarity-difference-replacement simplex approach) of global lichen diversity on ultramafic substrates (2314 reports of 881 taxa from 43 areas) displayed a zonal species distribution in different climate zones rather than an azonal distribution driven by the shared substrate. Accordingly, variations in the frequency of functional attributes reflected reported adaptations to the climate conditions of the different geographic areas. At the regional scale, higher similarity and lower species replacement were detected at each altitude, independent from the substrate, suggesting that altitude-related climate factors prevail over putative substrate-factors in driving community assemblages. In conclusion, data do not reveal peculiarities in lichen diversity or the frequency of functional traits in ultramafic areas.

Keywords Functional traits $\cdot$ Lichen $\cdot$ Koppen-Geiger climate zones $\cdot$ Serpentine $\cdot$ Ultramafic

\section{Introduction}

Deficiency in plant essential nutrients, reduced water availability, combined with $\mathrm{Mg}: \mathrm{Ca}$ imbalance and often high $\mathrm{Ni}, \mathrm{Cr}$ and $\mathrm{Co}$ - altogether known as the "serpentine factors"- result in unique phanerogamic floras in ultramafic ecosystems (Harrison and Rajakaruna 2011). Ultramafic areas are generally distinct from surrounding non-ultramafic ones in that they harbor low vascular plant diversity and density, leading to sparsely vegetated landscapes (Brooks 1987, with refs therein). Moreover, ultramafic ecosystems display a spectacular richness of plant endemism, species showing exceptional capacity for metal accumulation (i.e. hyperaccumulators; van der Ent et al. 2013), ecotypes with peculiar morphologies (serpentinomorphoses, sensu Pichi-Sermolli 1948), abundance of species characterized by disjunct distributions (Rajakaruna 2017), and the co-presence of acidophytic and basiphytic species (e.g. O'Dell and Rajakaruna 2011; van der Ent et al. 2013; Anacker 
2014). These features have long fascinated botanists, making ultramafic environments a model system to explore plant adaptation and evolution by natural selection (Harrison and Rajakaruna 2011).

Not surprisingly, investigations on lichens in ultramafic areas have often been discussed with reference to the well-documented peculiarities of higher plant communities on ultramafics (Favero-Longo et al. 2004). However, the recognizability of any peculiarity in lichen communities on ultramafics is still a matter of contention (Favero-Longo 2014). Reduced lichen diversity and abundance have been recognized, but only on certain ultramafic lithologies (Favero-Longo et al. 2015, with refs therein). Many lichen species previously regarded as exclusive to serpentinized ultramafic rocks were subsequently reported from other (mafic) rocks (Favero-Longo et al. 2004). Observations of 'serpentinomorphoses' such as stenophyllism or dwarfism were occasionally described in the first half of the last century (Suza 1927; Sambo 1937), but have not been subsequently confirmed. Nevertheless, when lichen diversity has been compared between adjacent ultramafic and non-utramafic areas, some differences have often been noted, suggesting some substrate-related peculiarities (Favero-Longo et al. 2004; Favero-Longo 2014, with refs therein). Recent work has suggested that other biotic or abiotic factors, rather than rock or soil chemistry, may primarily drive species- and community-level processes in the case of lichens, potentially explaining these peculiarities (Favero-Longo and Piervittori 2009; Rajakaruna et al. 2012; Favero-Longo et al. 2015). However, no investigations have focused on this topic because of the difficulties in comparing studies from different ultramafic areas in different parts of the world.

In this context, the study of functional traits of species (sensu Violle et al. 2007) and their direct links to environmental factors has been shown to allow comparisons among different ecosystems and across regions (Giordani et al. 2012). In the case of lichens, the study of morpho-physio-phenological traits influencing growth, reproduction and survival have clarified relationships between lichen traits and environmental factors, including disturbance, solar radiation, water drainage, fire, land management, and climate gradients (Giordani et al. 2014; Nelson et al. 2015; Giordani et al. 2016). Similar analyses of functional traits of lichens with respect to substrate and other macro- and micro-environmental factors have not been performed with respect to lichen communities in ultramafic areas alone or in comparison with those on non-ultramafic substrates. Only some correlations of substrate-related elemental concentrations in thalli with fecundity and secondary metabolite patterns have been suggested for lichens of the genus Xanthopamelia on felsic and mafic lithologies (Deduke et al. 2016; Matteucci et al. 2017).

In this paper, we examine the lichen biota in ultramafic areas with reference to species-specific functional traits. Our first objective was to survey diversity and functional traits of lichens in ultramafic areas through- out the world, evaluating the occurrence of local trends of adaptation to geographically-related environmental pressures or of common, ultramafic-related fitness signatures. With this regard, we updated the checklist of lichen reports from ultramafic areas (with respect to Favero-Longo et al. 2004), classified the ultramafic areas-located in different climate regions based on the updated World Map of the Koppen-Geiger climate classification (Kottek et al. 2006; Rubel et al. 2017) — on the basis of the presence or absence of lichen species, and examined whether there is a correlation between lichen diversity and functional traits with their distribution across climate regions. Our second objective was to examine whether a relationship can be detected between substrate and functional traits which cannot be explained by other environmental factors. This work was conducted at a regional scale due to the difficulty in expanding a similar investigation to a wider spatial scale. In particular, diversity and functional traits were surveyed in lichen communities on ultramafic and non-ultramafic substrates in areas of Valle d'Aosta (NorthWest Italy) at different altitudes, evaluating whether a primary influence of lithology can be detected or whether other environmental factors related to altitude prevail in driving community-level processes at a regional scale.

\section{Methods}

\section{World literature survey}

A survey was conducted of published records of lichens on ultramafic rocks of stratiform, concentrically zoned, ophiolitic, and high temperature peridotite complexes (see Malpas 1992) throughout the world. Forty-nine pertinent publications were utilized (with some references therein), including floristic and vegetation studies and species reports for 43 ultramafic areas. For each area, information was collected on the ultramafic lithology (e.g. non-serpentinized or serpentinized peridotite) and the climate (according to the updated world map of Koppen-Geiger climate classification; Kottek et al. 2006; Rubel et al. 2017) (Table 1). A comprehensive list of lichen species reported from ultramafic areas was compiled, with nomenclature updated according to Index Fungorum (2017), Consortium of North American Lichen Herbaria (2017) and Nimis (2016). The $\alpha$ diversity per area and species frequency in the overall areas were analysed.

Areas with at least 20 species $(n=26$ areas) were classified (Unweighted Pair Group Mean Average, UPGMA, method, Phi as dissimilarity coefficient, arbitrary resolution of ties; Podani 2001) on the basis of the presence/absence of species with at least two reports. The relative importance of components of $\gamma$-diversity [i.e. similarity $(\mathrm{S})$, relativized richness difference (D), and relativized species replacement $(\mathrm{R})$ ] was evaluated for all 


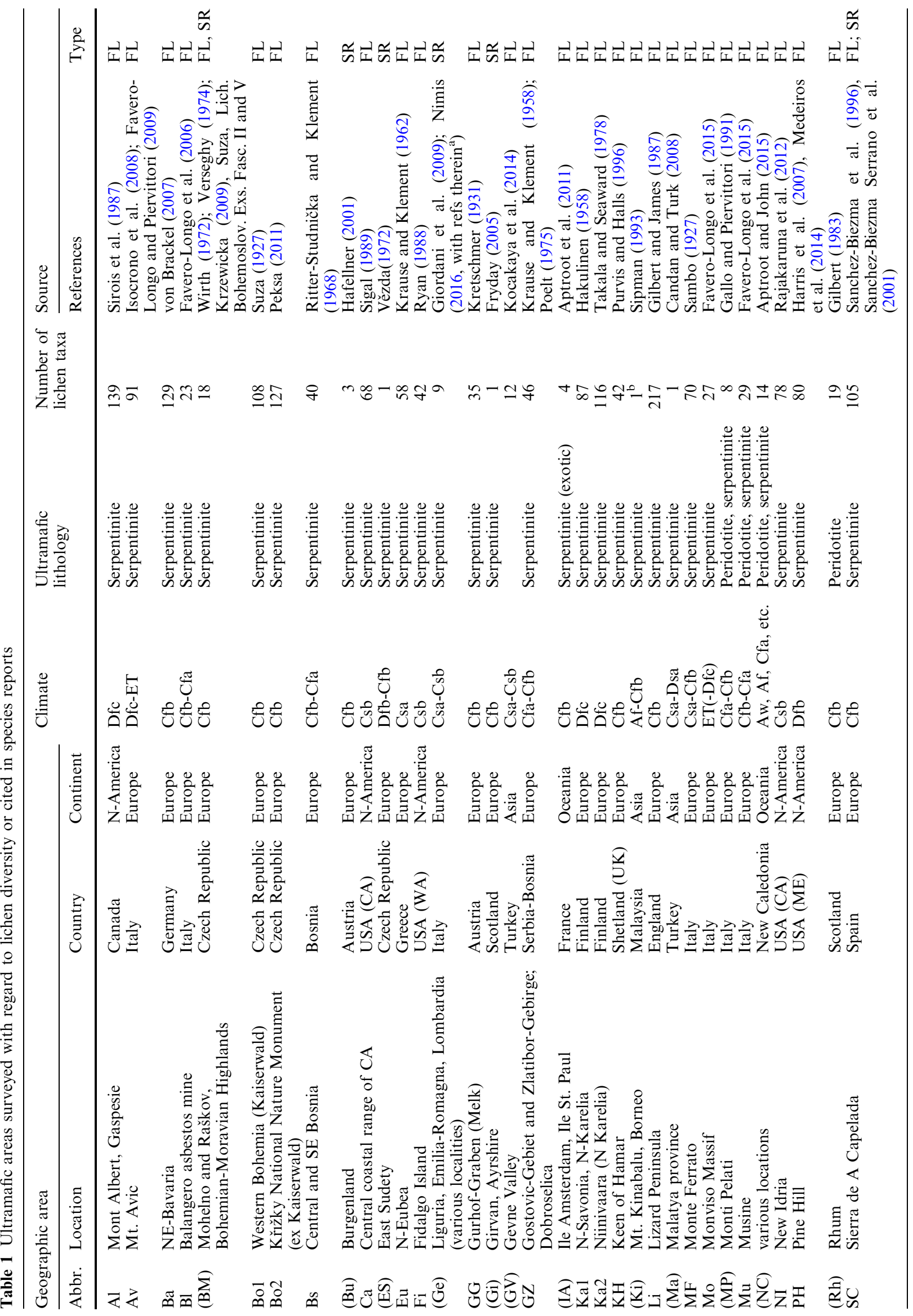




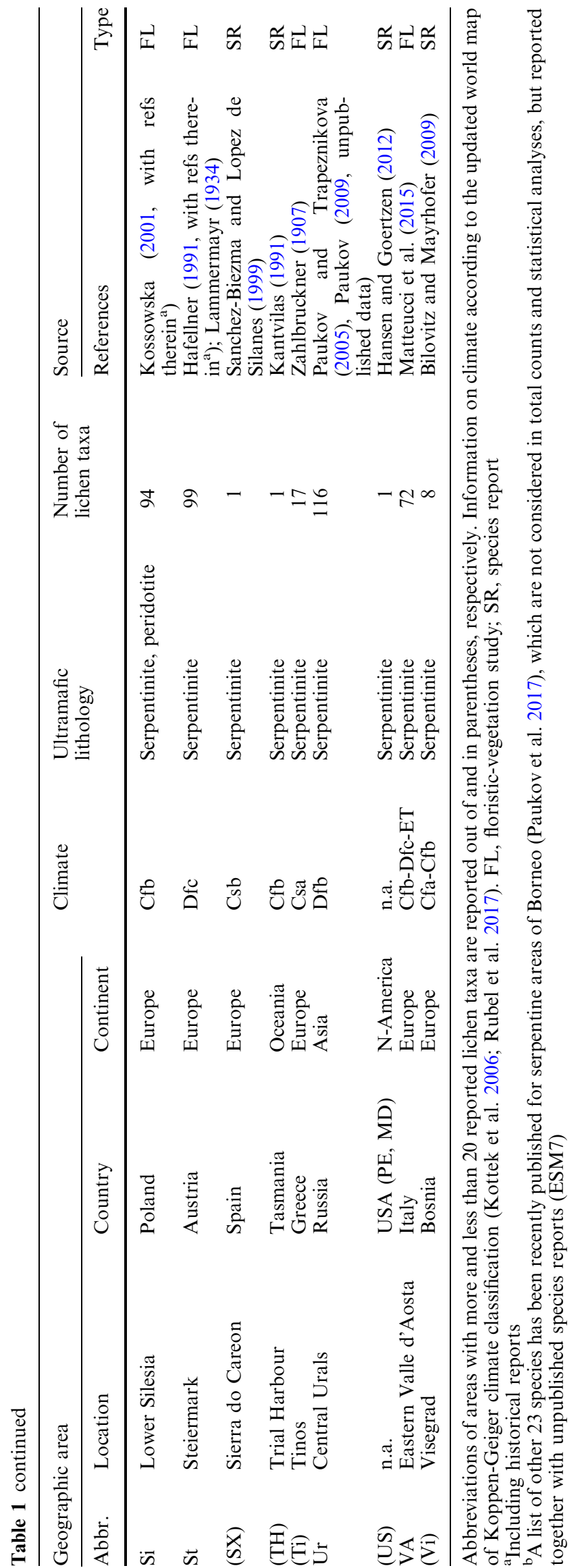

combinations of these areas by analysing the matrix of species presence/absence with SDR Simplex software using the Simplex method (SDR Simplex; Podani and Schmera 2011). Similarity (S) was calculated following the Jaccard coefficient of similarity:

$\mathrm{S}_{\mathrm{Jac}}=a / n$

where $a$ is the number of species shared by the two plots, and $n$ is the total number of species.

The relativised richness difference (D) was calculated as the ratio of the absolute difference between the species numbers of each site $(b, c)$ and the total number of species, $n$ :

$\mathrm{D}=|b-c| / n$.

Relativised species replacement ( $\mathrm{R}$ ) was calculated as:

$\mathrm{R}=2 \times \min \{b, c\} / n$.

A relativised $\beta$-diversity as the sum of $\mathrm{R}+\mathrm{D}$, a relativised richness agreement as the sum of $\mathrm{R}+\mathrm{S}$, and a relativised nestedness as the sum of $S+D$ were also calculated for each pair of areas following Podani and Schmera (2011).

Regional field survey: study area, sampling design and statistical analyses

Lichen diversity was surveyed on serpentinized-ultramafic rocks and non-ultramafic lithologies, including granite, gneiss and micaschist, in nine areas of Valle d'Aosta (North-West Italy) distributed at three different altitudes (approx. 550, 1600 and $2250 \mathrm{~m}$; Table 2). The intra-alpine Valle d'Aosta (approx. $3200 \mathrm{~km}^{2}$ ) displays a fairly dry semi-continental climate, ranging from arid (BSk), to temperate (Cfa, Cfb) and boreal (Dfc)-alpine $(\mathrm{ET}, \mathrm{EF})$ at the three surveyed altitudes (Rubel et al. 2017).

At each site, delimited on the basis of the homogeneous occurrence of a lithology at a certain altitude, four plots were defined by randomly drawing geographical coordinates determined by a GPS (Garmin 12; Garmin International: Olathe, KS, USA) and surveyed during the summer of 2012 and 2013. In each plot, three independent $50 \times 50 \mathrm{~cm}$ sub-plots were established on the three rock surfaces closest to the randomly extracted coordinate and sharing the following (micro-)environmental features: direct solar irradiation, regular micromorphology, slope $<30^{\circ}$, absence of cracks, soil deposits and mosses. Each plot was surveyed using a square grid divided into 25 quadrats $(10 \times 10 \mathrm{~cm})$. The frequency of lichen species within each sub-plot (as the sum of their occurrences within the grid quadrats) was estimated visually. Lichens were identified using Clauzade and Roux (1985), Wirth (1995), Smith et al. (2009) and monographic descriptions. Nomenclature follows Nimis (2016). Sample vouchers were deposited at the 
Table 2 Areas surveyed with regard to lichen diversity in Valle d'Aosta

\begin{tabular}{|c|c|c|c|c|c|}
\hline \multicolumn{3}{|c|}{ Geographic area } & \multirow{2}{*}{$\begin{array}{l}\text { Altitude } \\
\text { (m a.s.l.) }\end{array}$} & \multirow[t]{2}{*}{ Lithology } & \multirow{2}{*}{$\begin{array}{l}\text { Number of lichen } \\
\text { taxa }\end{array}$} \\
\hline Abbrev. & Municipality (location) & UTM coordinates $(\mathrm{m})^{\mathrm{a}}$ & & & \\
\hline GAB & Gressoney-La-Trinite (Gabiet) & N 5079056, E 410423 & 2340 & Serpentinite & 25 \\
\hline GSB & $\begin{array}{l}\text { Saint-Remy-en-Bosses } \\
\text { (Grand Saint Bernard) }\end{array}$ & N 5079930, E 358973 & 2250 & Micaschist and gneiss & 34 \\
\hline OLL & Ollomont & N 5081308, E 368403 & 1640 & Metabasite, chloristoschist & 53 \\
\hline SAU & Courmayeur (Pavillon-Saussurea) & N 5077501, E 340665 & 2200 & Granite and gneiss & 27 \\
\hline THU & La Thuile (Les Granges) & N 5066202, E 341821 & 1640 & Micaschist & 34 \\
\hline TRI & Gressoney-La-Trinite (village) & N 5075483, E 408645 & 1680 & Serpentinite & 32 \\
\hline TSA & Saint Cristophe (Tsatelet) & N 5067816, E 370274 & 570 & Micaschist & 35 \\
\hline VER & Verres (Castle) & N 5058403, E 398430 & 520 & Serpentinite & 30 \\
\hline VIN & Saint-Vincent & N 5066303, E 395728 & 650 & Serpentinite & 28 \\
\hline
\end{tabular}

${ }^{\text {a }}$ The coordinates (UTM ED50) of one of the four randomly extracted plots are reported for each area

Cryptogamic Herbarium of the University of Torino (HB-TO Cryptogamia).

Areas, plots and sub-plots were classified (UPGMA, Euclidean as dissimilarity coefficient, arbitrary resolution of ties; Podani 2001) on the basis of the frequency of species. The sub-plot level matrix of species frequency was analysed with SDR Simplex software using the simplex method (SDR simplex; Podani and Schmera 2011), as previously detailed.

\section{Functional traits and statistical analyses}

For each lichen species listed from at least five ultramafic areas throughout the world (i.e. species reported in $>$ $20 \%$ of sites with at least 20 species), and for each species listed from ultramafic and non-ultramafic sites of Valle d'Aosta, we defined a set of functional traits (i.e. components of their phenotype that determine their effects on biological processes and their response to environmental factors) (Violle et al. 2007). Following Giordani et al. (2016, with refs therein), we selected traits associated with reproduction and ecophysiology (Table 3). Several traits play a decisive role in the phases of dispersal and establishment of new thalli: most of them include attributes related to morphological characteristics of the spores, such as their shape, number, dimension and color (Armstrong 1981; Morando et al. 2017). Some eco-physiological functions, such as substrate colonization, evapotranspiration or photon absorption, are strictly related to lichen growth form (Palmqvist 2000), whereas some features (e.g. thallus and epithecium colors or the presence of pruina) are involved in the protection from solar radiation (Giordani et al. 2003). In this regard, secondary metabolites also play protective roles from negative effects of solar radiation, but are also used to regulate $\mathrm{pH}$ and metal homeostasis and as a defense from other abiotic and biotic stresses (Elix and Stocker-Worgotter 2008; Hauck et al. 2009, 2013). Functional attributes were assigned to each trait (i.e. values or modalities taken by the trait and varying along environmental gradients and/or through time; Giordani et al. 2016). A multidimensional functional space was identified for both the world and regional datasets (lichens found on ultramafics and lichens found on both ultramafic and non-ultramafic substrates, respectively) placing each taxon according to its functional niche and calculating functional distances between species in each dataset.

In particular, the matrices of species presence/absence (world dataset) or frequency (regional dataset, at the plot and sub-plot level level), and those of functional traits were processed through a canonical correspondence analysis (CCA), which partitions variation explained by each variable and constructs a model of significant variables (CCA using biplot scaling for interspecies distances, Hill's scaling for inter-sample distances; choosing forward selection of variables option; performing Monte Carlo permutation test on the first and all ordination axes) (Ter Braak and Verdonschot 1995). The ordinations were performed using CANOCO 4.5 (Ter Braak and Šmilauer 2002).

\section{Results}

\section{World survey}

A total of 2314 reports of lichens, attributable to 881 specific and subspecific taxa, were listed for ultramafic substrates worldwide (Electronic Supplementary Material 1 (ESM1)). Some tens of other reports, revealing taxonomic uncertainty because of incomplete information (e.g. absence of authority), were excluded from the counts. Most of the taxa were only reported in one $(52 \%)$ or two $(20 \%)$ ultramafic areas, while 15 and $4 \%$ of taxa in at least five and ten areas, respectively (Fig. 1a). Candelariella vitellina was the most commonly reported species on ultramafic substrates, being listed in 28 out of the 43 considered areas. The highest specific richness was reported for the Lizard Peninsula (217 species, Gilbert and James 1987; Fig. 1b), but the different, and not always specified, extent of the surveyed 
Table 3 List of considered functional traits, with the related functional attributes assigned with reference to Smith et al. (2009) and Nimis (2016)

\begin{tabular}{|c|c|c|c|}
\hline Functional trait & Abbrev. & Functional trait attributes & Abbrev. \\
\hline \multirow[t]{3}{*}{ Reproductive strategy } & \multirow[t]{3}{*}{ REPR } & Mainly sexual by means of ascospores & $\mathrm{Se}$ \\
\hline & & $\begin{array}{l}\text { Mainly asexual, either by soredia or isidia } \\
\text { or fragmentation }\end{array}$ & As \\
\hline & & With both sexual and asexual structures & $\mathrm{Sa}$ \\
\hline \multirow[t]{3}{*}{ Ascocarp type } & \multirow[t]{3}{*}{ ATYP } & With lecanorine apothecia & $\mathrm{Ln}$ \\
\hline & & With lecideine apothecia & $\mathrm{Ld}$ \\
\hline & & With perithecia or others & $\mathrm{Pe}$ \\
\hline \multirow[t]{3}{*}{ Number of ascospores in each ascum } & \multirow[t]{3}{*}{ SNUM } & $<8$ spores & $<8$ \\
\hline & & 8 spores & $=8$ \\
\hline & & $>8$ spores & $>8$ \\
\hline \multirow[t]{2}{*}{ Shape of spores } & \multirow[t]{2}{*}{ SSHA } & Globose, sub-globose, ovate, elissoid & El \\
\hline & & Different & $\mathrm{Di}$ \\
\hline \multirow[t]{3}{*}{ Number of septa in the spores } & \multirow[t]{3}{*}{ SSEP } & Non septate & Ns \\
\hline & & 1 septum & Os \\
\hline & & $>1$ septum & Ps \\
\hline \multirow[t]{5}{*}{ Length of the spores } & \multirow[t]{5}{*}{ SLEN } & Small $(<5 \mu \mathrm{m})$ & $\mathrm{Sl}$ \\
\hline & & Small-medium $(5-10 \mu \mathrm{m})$ & $\mathrm{Sm}$ \\
\hline & & Medium-large $(11-20 \mu \mathrm{m})$ & Ml \\
\hline & & Large $(21-40 \mu \mathrm{m})$ & $\mathrm{La}$ \\
\hline & & Extra-large $(>40 \mu \mathrm{m})$ & $\mathrm{Xl}$ \\
\hline \multirow[t]{3}{*}{ Color of the spores } & \multirow[t]{3}{*}{ SCOL } & Hyaline & Ia \\
\hline & & From hyaline to dark & $\mathrm{Ch}$ \\
\hline & & Dark pigmented & $\mathrm{Dp}$ \\
\hline \multirow[t]{5}{*}{ Growth form } & \multirow[t]{5}{*}{ GROW } & Crustose & $\mathrm{Cr}$ \\
\hline & & Placodioid & $\mathrm{Cp}$ \\
\hline & & Squamulose & $\mathrm{Sq}$ \\
\hline & & Foliose & Fo \\
\hline & & Fruticose & $\mathrm{Fr}$ \\
\hline \multirow[t]{3}{*}{ Thallus continuity } & \multirow[t]{3}{*}{ TCON } & Continuous & $\mathrm{Co}$ \\
\hline & & Discontinuous or not visible & Ds \\
\hline & & With variable continuity & De \\
\hline \multirow[t]{3}{*}{ Photosynthetic strategy } & PHOT & Photosynthetic with chlorococcoid green algae & $\mathrm{Ch}$ \\
\hline & & Photosynthetic with Trentepohlia pigments & $\operatorname{Tr}$ \\
\hline & & Photosynthetic with cyanobacteria pigments & $\mathrm{Cy}$ \\
\hline Color of the thallus & TCOL & Pale & $\mathrm{Pa}$ \\
\hline & & Grey & $\mathrm{Gr}$ \\
\hline & & Brown-black & $\mathrm{Bb}$ \\
\hline & & Orange-yellow & Oy \\
\hline & & Green & Gn \\
\hline Occurrence of pruina & PRUI & Present & $\mathrm{Ye}$ \\
\hline & & Absent & No \\
\hline & & Sometimes present & Yn \\
\hline Color of the epithecium/disc & ACOL & Black & $\mathrm{B} 1$ \\
\hline & & Brown & $\mathrm{Br}$ \\
\hline & & Others & Ot \\
\hline $\begin{array}{l}\text { Production of lichen secondary metabolites } \\
\text { (categories according to Huneck and }\end{array}$ & & $\begin{array}{l}\text { Production in all thalli of at least one metabolite } \\
\text { of the listed category }\end{array}$ & Yes \\
\hline Yoshimura 1996): & & $\begin{array}{l}\text { Production in some thalli of at least one metabolite } \\
\text { of the listed category }\end{array}$ & $\mathrm{Y} / \mathrm{N}$ \\
\hline & & No production of metabolites of the listed category & No \\
\hline Aliphatic compounds & Alip & & \\
\hline Quinones & Quin & & \\
\hline Chromones and xanthones & Chro & & \\
\hline Pulvinic derivatives & Pulv & & \\
\hline Depsides & Deps & & \\
\hline Depsidones & Dops & & \\
\hline Dibenzofuranes & Dibe & & \\
\hline Terpenoids & Terp & & \\
\hline
\end{tabular}

ultramafic areas, together with the heterogeneity of the surveying approaches, may not allow a consistent identification of biodiversity hotspots.

Twenty-six areas, distributed between Europe (up to Urals; $81 \%$ ) and North (N-) America (19\%), hosted more than 20 species. The classification of these areas on the basis of species presence/absence data resulted in four main groups (I-IV; Fig. 2). Group I included areas $(n=4)$ in western coasts of Europe and N-America with warm temperate climate, fully humid and with a warm summer ( $\mathrm{Cfb}$, or $\mathrm{Csb}$ bordering on $\mathrm{Cfb}$ in the case of Fi). Group II included areas $(n=9)$ with $\mathrm{Cfb}$ climate 

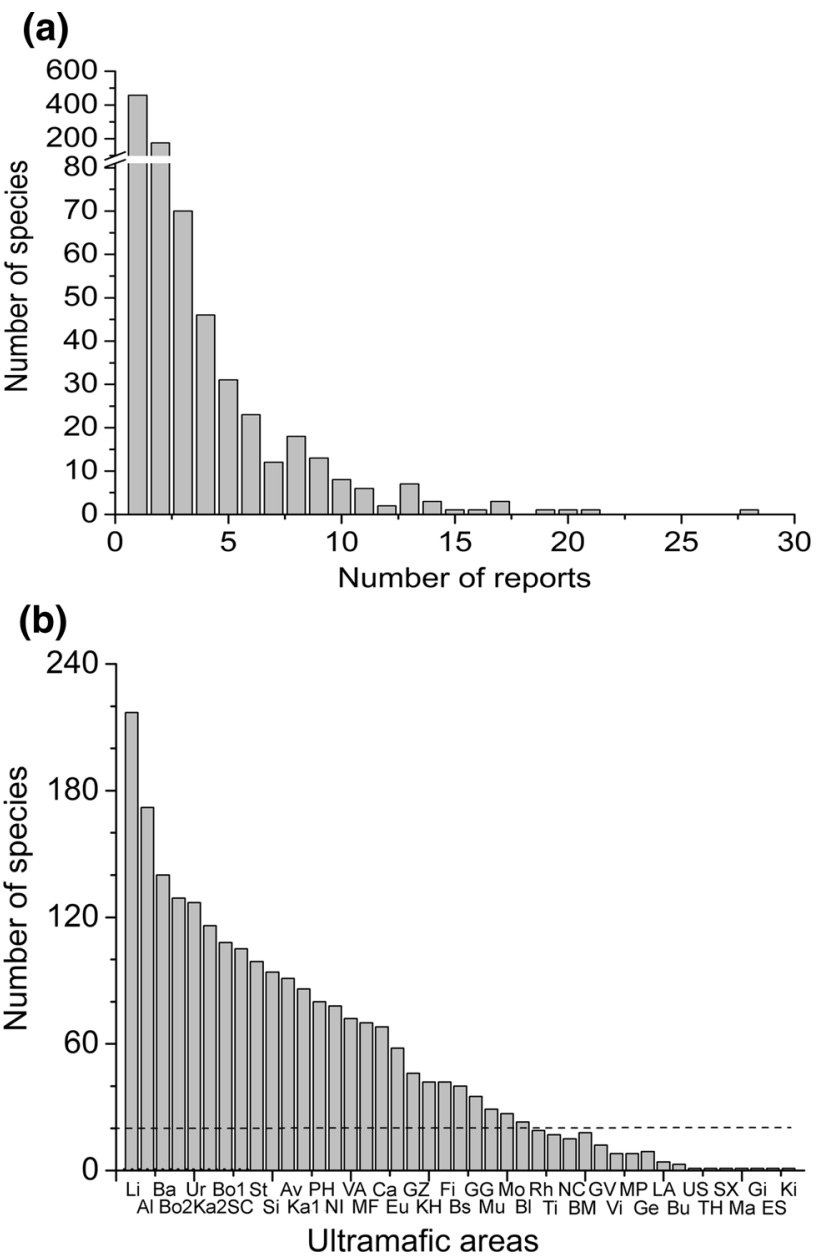

Fig. 1 Frequency and diversity of lichen taxa from ultramafic areas worldwide. a Number of taxa which were reported from 1 to 28 times from the ultramafic areas considered; $\mathbf{b}$ number of species listed through the 43 ultramafic areas (abbreviations according to Table 1; areas with more than 20 species-dotted line-were considered for statistical analyses)

in central Europe, and areas of northern Europe and northern N-America with snow climates, fully humid and with a warm summer (Dfb) or with cold summer and cold winter (Dfc). Group III included (sub-) Mediterranean areas of Europe with warm temperate climate wih dry, hot summer (Csa) or more humid areas with hot to warm summer (Cfa-Cfb borders). Group IV included areas of the Alps $(n=6)$, with climates ranging from warm temperate with hot summer, at the border with the Po Plain, to snow to polar climate at highest altitudes (from $\mathrm{Cfa}-\mathrm{Cfb}$ to ET). Areas of California $(n=2)$ with warm temperate climate with dry and hot summer (Csb) also clustered within this group.

The SDR analysis (Table 4; Fig. 3a) showed a very low species similarity $(\mathrm{S})$, whereas the species replacement $(\mathrm{R})$ was the major component of $\gamma$-diversity. Relativized $\beta$-diversity $(\mathrm{R}+\mathrm{D})$ was approximately $90 \%$.

A number of functional attributes largely characterized the lichen species more widely reported from ultramafic areas (i.e. reported from at least five ultra- mafic areas; Table 5, ESM2): presence of chlorococcoid photobiont, a crustose continuous thallus without pruina, predominance of sexual reproduction, and asci with 8 ellipsoid hyaline spores without septa. Such attributes were dominant through all the groups of ultramafic areas I-IV; however, each group had remarkable relative variations in the frequency of functional attributes (see $\Delta \mathrm{Gr}$ in Table 5), as also displayed by CCA-I (Fig. 4, ESM3). The analysis of the world dataset of species presence/absence and the related functional traits of species extracted four axes which accounted for $66.1 \%$ of ultramafic area-functional trait relationships. All canonical axes were significant (Monte Carlo test, $P$ value $=0.002)$. The first axis $(34.9 \%$ of correlation) was characterized by growth form (GROW, weighted correlation, w.c., 0.71), which was the factor exhibiting the higher conditional effect according to forward selection ( $F$ value $6.58, P$ value 0.002 ) and reproductive strategy (REPR, w.c. $0.62, F$ value $2.46, P$ value 0.002 ). The production of aliphatic compounds (Alip, $F$ value 2.44, $P$ value 0.002 ), occurrence of pruina (PRUI, $F$ value 1.87, $P$ value 0.016 ) and spore shape (SSHA, $F$ value $2.17, P$ value 0.006 ) also showed significant conditional effects, being mostly related to axes $2(12.0 \%$ of correlation), $3(10.7 \%)$ and $4(8.5 \%)$, respectively. Ultramafic areas of groups II, III and IV (see Fig. 2) scattered separately along the first axis, while those of group I were separated along the second axis. Group II was positively correlated with GROW and REPR, with reference to higher occurrence of macrolichens (foliose and fruticose) and species with predominant asexual reproduction. Groups III and IV showed no correlation and a negative correlation, respectively, with GROW and REPR, whereas they were positively correlated to Alip and PRUI, indicating the production of aliphatic compounds and pruina on the thallus surface. Group I was instead negatively or poorly correlated with both GROW and REPR and Alip and PRUI.

\section{Regional survey}

A total of 111 lichen taxa were recorded through the nine areas surveyed in Valle d'Aosta, $\alpha$-diversity per area ranging from 25 to 53 species (ESM4). Species diversity was not significantly different between ultramafic and non-ultramafic substrates or between different altitudes when evaluated either per area or per plot (ANOVA, $P>0.005$ ), although the highest numbers of species characterized were from non-ultramafic areas and plots at medium altitudes (Table 2; Fig. 5). On all substrates, Candelariella vitellina was the most commonly reported species in all low altitude areas, while Rhizocarpon geographicum was the most commonly reported species at medium and high altitudes. Only these two species, together with Circinaria caesiocinerea, occurred in all of the surveyed areas. Species exclusive of ultramafic and non-ultramafic areas were 14 and $44 \%$, respectively. Species occurring at all three altitudes were $16 \%$, while 

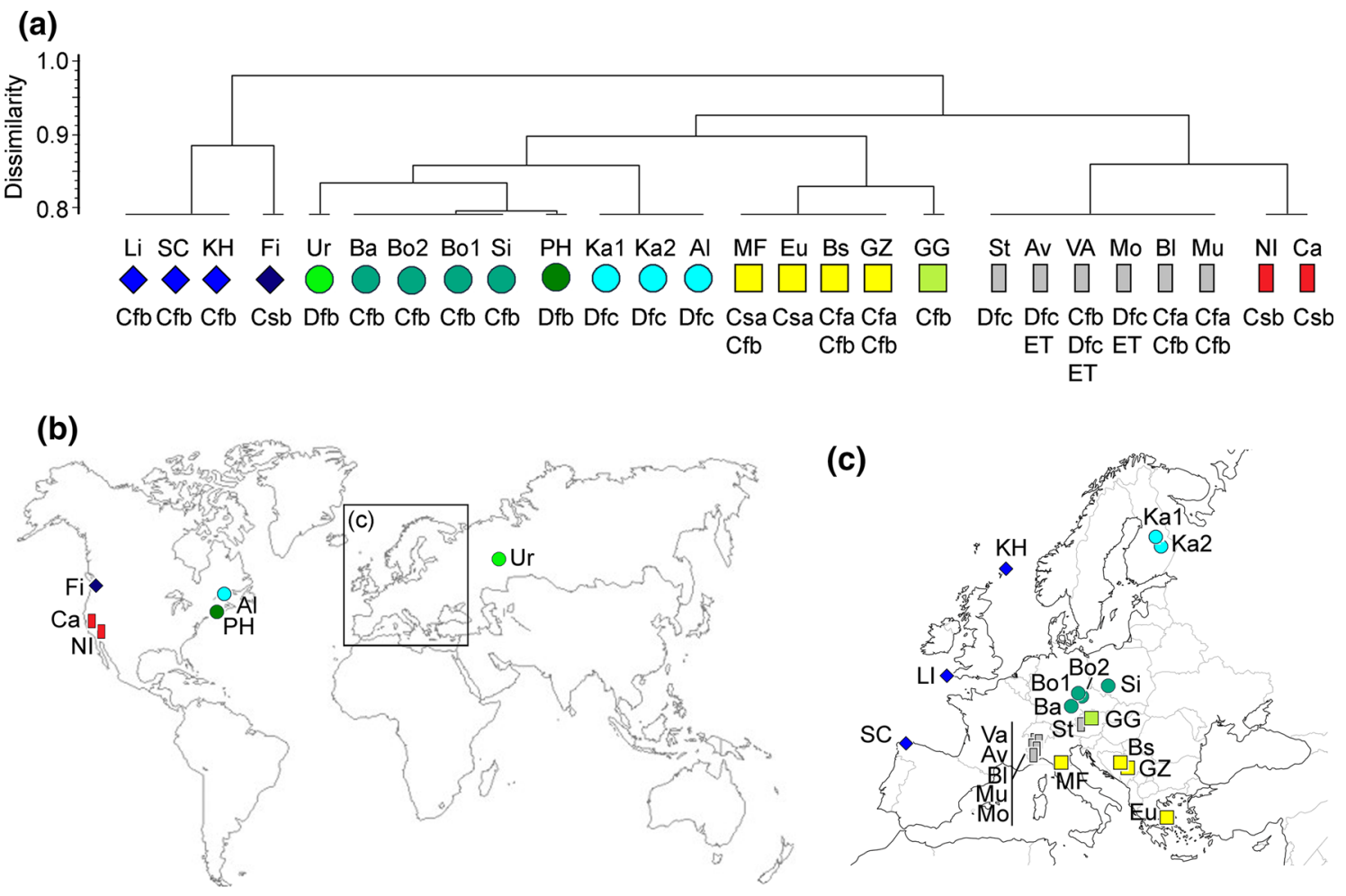

Fig. 2 Classification of ultramafic areas $(n=26$, with $>20$ lichen taxa) on the basis of species presence/absence data and their world distribution. a Unweighted Pair Group Mean Average (UPGMA) clustering: group I, diamonds; group II, circles; group III, squares; group IV, boxes. Different symbol colours indicate

different sub-groups (not named). Abbreviations for areas are listed in Table 1; information on climates follows Kottek et al. (2006) and Rubel et al. (2017). Cophenetic correlation; 0.82. b, c Distribution of the classified ultramafic areas through the world (Europe in inset c)

Table 4 Percentage contribution from the SDR simplex analyses of lichen communities in the ultramafic areas considered at the world scale and ultramafic and non-ultramafic areas surveyed at the regional scale at different altitudes

\begin{tabular}{|c|c|c|c|c|c|c|c|}
\hline & $\mathrm{S}$ & $\mathrm{R}$ & $\mathrm{D}$ & $\mathrm{R}+\mathrm{D}$ & $\mathrm{S}+\mathrm{R}$ & $\mathrm{S}+\mathrm{D}$ & MATRIX FILL $(\%)$ \\
\hline World survey & 10.5 & 55.5 & 34.0 & 89.5 & 66.0 & 44.3 & 10.0 \\
\hline Regional survey (ultramafic + non-ultramafic) & 24.7 & 56.1 & 19.1 & 75.2 & 88.8 & 43.8 & 9.8 \\
\hline Regional ultramafic & 27.6 & 54.8 & 17.6 & 72.4 & 82.4 & 45.2 & 16.4 \\
\hline Regional non-ultramafic & 24.9 & 54.6 & 20.5 & 75.0 & 79.5 & 45.4 & 12.0 \\
\hline Regional low altitude & 27.4 & 57.6 & 15.0 & 72.6 & 85.0 & 42.4 & 17.9 \\
\hline Regional medium altitude & 33.6 & 45.2 & 21.2 & 66.4 & 78.8 & 54.8 & 16.6 \\
\hline Reg high altitude & 35.3 & 43.8 & 20.9 & 64.7 & 79.1 & 56.2 & 20.3 \\
\hline
\end{tabular}

$\mathrm{S}$ (relative similarity), $\mathrm{R}$ (relative replacement), $\mathrm{D}$ (relative richness difference), $\mathrm{R}+\mathrm{D}$ (relative $\beta$-diversity), $\mathrm{S}+\mathrm{R}$ (relative richness agreement), $\mathrm{S}+\mathrm{D}$ (relative nestedness)

14,24 and $11 \%$ were exclusive to areas at low, medium and high altitudes, respectively.

The classification of the nine areas on the basis of lichen frequency data resulted in the separation of three main groups, each including ultramafic and non-ultramafic areas, and mostly reflecting the three surveyed altitudes (Fig. 6). A similar pattern was also obtained by analysing the matrix at the plot and sub-plot level (not shown).

The SDR analysis showed a strongly higher similarity (S) for ultramafic and non-ultramafic areas surveyed at the regional scale than that calculated for the world survey limited to ultramafic areas (Table 4; Fig. 3b). Richness difference (D) was instead lower, while species replacement (R) was analogous. Similar values were obtained when the SDR analysis was performed separately for non-ultramafic and ultramafic areas, the latter showing only a slight increase in similarity and decrease in richness difference (Table 4; Fig. 3c, d). Instead, the SDR analysis performed separately for the three altitudes showed remarkably higher similarity and lower species replacement in the case of areas at medium and high altitudes (Table 4; Fig. 3e, f).

The functional attributes that dominated the species listed from ultramafic areas at the global scale were also dominant in the lichen species documented at the regional level in ultramafic and non-ultramafic areas of Valle d'Aosta (ESM5). The frequencies of functional attributes 
(a)

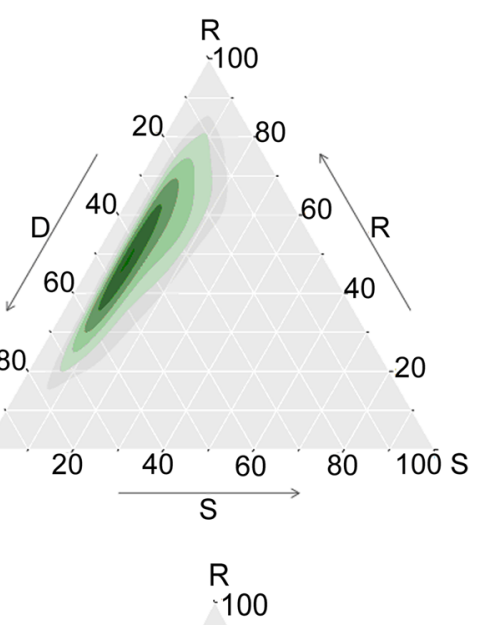

(c)

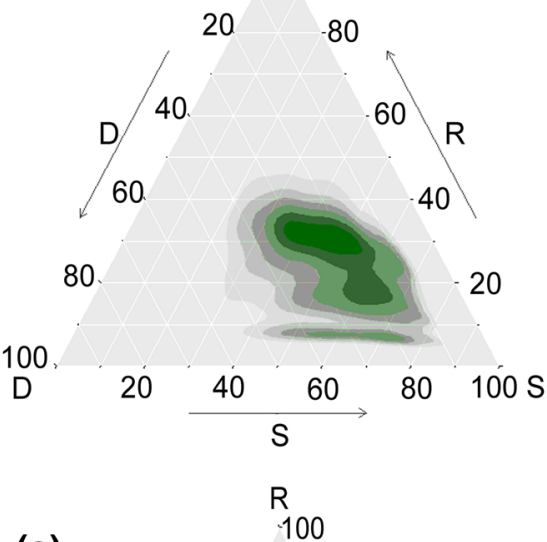

(e)

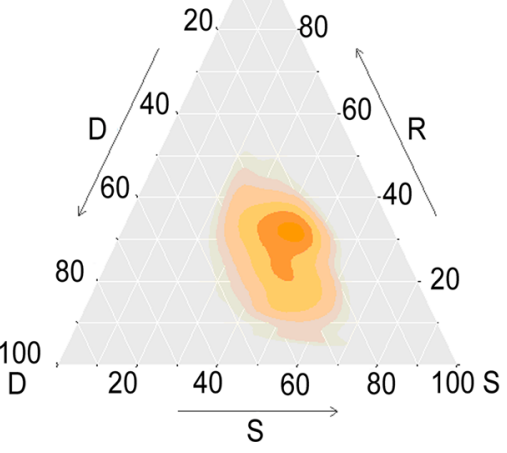

Fig. 3 SDR simplex ternary plots for the world (a) and regional (b-f) datasets. Color patterns refer to Kernel densities of site pairs included in the datasets. World level a: all pairs of ultramafic areas. Regional level: $\mathbf{b}$ all pairs of sub-plots, $\mathbf{c}$ all pairs of subplots in ultramafic areas, $\mathbf{d}$ all pairs of sub-plots in non-ultramafic

detected at the regional level, in particular, were close to values calculated for group IV of ultramafic areas, including alpine areas (Table 5). Higher variations in the frequency of attributes (including vegetative, reproductive and metabolic traits) were observed among species from different altitudes relative to species from different substrates (see $\Delta \mathrm{U}-\mathrm{NU}$ and $\Delta$ alt in Table 5), as also indicated by CCA-II (Fig. 7, ESM6). The analysis of regional species frequency and related functional traits extracted four axes which only accounted for $64.8 \%$ of area-

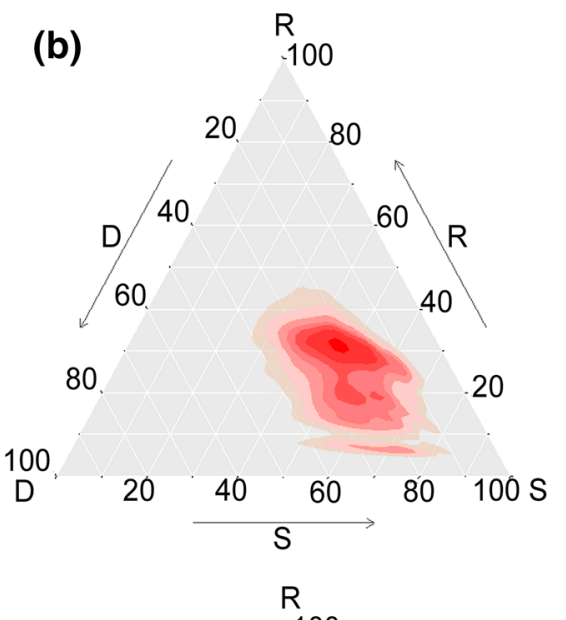

(d)

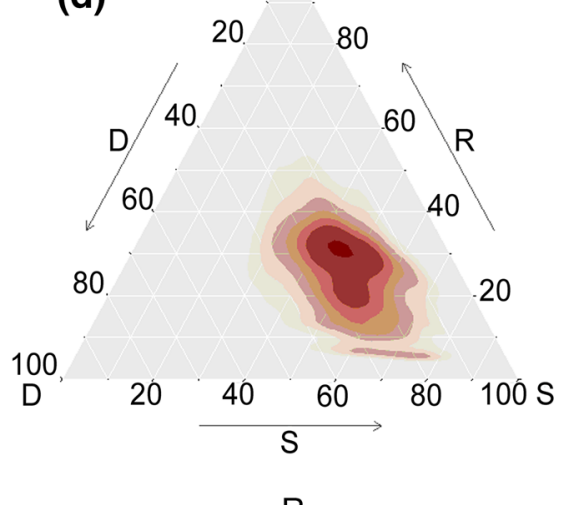

(f)

$R$
-100

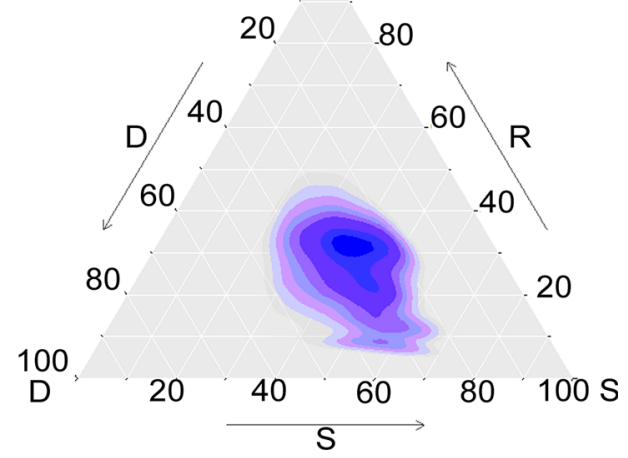

areas, e, f all pairs of sub-plots at medium and high altitudes, respectively. The abbreviations $\mathrm{S}, \mathrm{D}$ and $\mathrm{R}$ refer to relative similarity, richness difference, and species replacement, respectively

functional trait relationships. All canonical axes were significant (Monte Carlo test, $P$ value $=0.002$ ). The first axis (35.6\% of correlation) was largely characterized by the production of depsides (Deps, weighted correlation, w.c., 0.44) and aliphatic compounds (Alip, w.c. 0.36) and the type of ascocarp (ATYP, w.c. 0.37) and was negatively correlated with the occurrence of pruina (PRUI, w.c. -0.47 ), which were all factors exhibiting a high conditional effect according to forward selection (PRUI: $F$ value $3.04, P$ value 0.002; Deps: 2.29, 0.004; Alip 1.83, 
Table 5 Frequency (\%) of functional attributes assigned to each trait for species listed in ultramafic areas at the world level (altogether and separately for groups I-IV of the classification in Fig. 2) and in ultramafic and non-ultramafic areas surveyed at the regional level in Valle d'Aosta (altogether and separately, for ultramafic, U, and non-ultramafic, NU, areas, and for areas at low, l.alt., medium, m.alt., and high, h.alt., altitude). Maxima variations of attribute frequencies among groups I-IV at the world scale $(\Delta \mathrm{Gr})$ and among different substrates $(\Delta \mathrm{U}-\mathrm{NU})$ and altitudes $(\Delta \mathrm{alt})$ at the regional scale (underlined values indicate a higher maximum frequency variation among substrates or altitudes for a certain attribute). Abbreviations for functional traits and attributes are listed in Table 3

\begin{tabular}{|c|c|c|c|c|c|c|c|c|c|c|c|c|c|c|c|}
\hline \multirow{2}{*}{$\begin{array}{l}\text { Functional } \\
\text { traits }\end{array}$} & \multirow{2}{*}{$\begin{array}{l}\text { Functional } \\
\text { attributes }\end{array}$} & \multicolumn{6}{|l|}{ World } & \multicolumn{8}{|c|}{ Regional } \\
\hline & & Overall & Gr. I & Gr. II & Gr. III & Gr. IV & $\begin{array}{l}\Delta \mathrm{Gr} . \\
(\max )\end{array}$ & Overall & U & NU & 1.alt. & m.alt. & h.alt. & $\Delta \mathrm{U}-\mathrm{NU}$ & $\begin{array}{l}\Delta \text { alt. } \\
(\max )\end{array}$ \\
\hline \multirow[t]{3}{*}{ REPR } & $\mathrm{Se}$ & 65.2 & 64.6 & 63.7 & 69.6 & 76.2 & 12.5 & 86.2 & 88.7 & 86.0 & 86.8 & 85.3 & 90.2 & 2.7 & 4.9 \\
\hline & As & 6.1 & 2.5 & 6.5 & 3.8 & 4.8 & 3.9 & 0.9 & 0.0 & 1.1 & 0.0 & 1.3 & 0.0 & 1.1 & $\overline{1.3}$ \\
\hline & $\mathrm{Sa}$ & 28.8 & 32.9 & 29.8 & 26.6 & 19.0 & 13.9 & 12.8 & 11.3 & 12.9 & 13.2 & 13.3 & 9.8 & 1.6 & $\overline{3.5}$ \\
\hline \multirow[t]{3}{*}{ ATYP } & Ln & 46.2 & 49.4 & 46.8 & 41.8 & 47.6 & 7.6 & 33.0 & 30.6 & 31.2 & 24.5 & 29.3 & 47.1 & 0.5 & $2 \overline{2.5}$ \\
\hline & $\mathrm{Ld}$ & 50.0 & 45.6 & 50.0 & 54.4 & 47.6 & 8.9 & 59.6 & 61.3 & 61.3 & 73.6 & 61.3 & 45.1 & 0.0 & 28.5 \\
\hline & $\mathrm{Pe}$ & 3.8 & 5.1 & 3.2 & 3.8 & 4.8 & 1.8 & 7.3 & 8.1 & 7.5 & 1.9 & 9.3 & 7.8 & 0.5 & $\overline{7.4}$ \\
\hline \multirow[t]{3}{*}{ SNUM } & $<8$ & 6.8 & 3.8 & 7.3 & 7.6 & 6.0 & 3.8 & 7.3 & 9.7 & 7.5 & 11.3 & 9.3 & 7.8 & 2.2 & $\overline{3.5}$ \\
\hline & $=8$ & 90.2 & 91.1 & 90.3 & 89.9 & 89.3 & 1.0 & 81.7 & 83.9 & 79.6 & 77.4 & 78.7 & 80.4 & 4.3 & $\overline{3.0}$ \\
\hline & $>8$ & 3.0 & 5.1 & 2.4 & 2.5 & 4.8 & 2.6 & 11.0 & 6.5 & 12.9 & 11.3 & 12.0 & 11.8 & $\overline{6.5}$ & 0.7 \\
\hline \multirow[t]{2}{*}{ SSHA } & El & 93.2 & 94.9 & 92.7 & 94.9 & 97.6 & 4.9 & 94.5 & 96.8 & 94.6 & 94.3 & 96.0 & 96.1 & $\overline{2.2}$ & 1.7 \\
\hline & Di & 6.8 & 5.1 & 7.3 & 5.1 & 2.4 & 4.9 & 5.5 & 3.2 & 5.4 & 5.7 & 4.0 & 3.9 & $\overline{2.2}$ & 1.7 \\
\hline \multirow[t]{3}{*}{ SSEP } & Ns & 73.5 & 72.2 & 75.0 & 73.4 & 70.2 & 4.8 & 68.8 & 64.5 & 74.2 & 62.3 & 70.7 & 76.5 & $\overline{9.7}$ & 14.2 \\
\hline & Os & 13.6 & 16.5 & 12.9 & 13.9 & 17.9 & 5.0 & 26.6 & 29.0 & 21.5 & 34.0 & 22.7 & 19.6 & 7.5 & $\overline{14.4}$ \\
\hline & Ps & 12.9 & 11.4 & 12.1 & 12.7 & 11.9 & 1.3 & 4.6 & 6.5 & 4.3 & 3.8 & 6.7 & 3.9 & 2.2 & 2.9 \\
\hline \multirow[t]{5}{*}{ SLEN } & Sl & 3.8 & 2.5 & 4.0 & 2.5 & 2.4 & 1.7 & 9.2 & 6.5 & 10.8 & 11.3 & 9.3 & 11.8 & 4.3 & $\overline{2.4}$ \\
\hline & $\mathrm{Sm}$ & 11.4 & 12.7 & 12.1 & 7.6 & 11.9 & 5.1 & 22.0 & 21.0 & 21.5 & 22.6 & 18.7 & 13.7 & $\overline{0.5}$ & 8.9 \\
\hline & Ml & 63.6 & 60.8 & 64.5 & 69.6 & 64.3 & 8.9 & 52.3 & 58.1 & 50.5 & 49.1 & 54.7 & 56.9 & 7.5 & $\overline{7.8}$ \\
\hline & $\mathrm{La}$ & 14.4 & 19.0 & 13.7 & 15.2 & 17.9 & 5.3 & 13.8 & 11.3 & 15.1 & 13.2 & 13.3 & 15.7 & 3.8 & $\overline{2.5}$ \\
\hline & $\mathrm{Xl}$ & 6.8 & 5.1 & 5.6 & 5.1 & 3.6 & 2.1 & 2.8 & 3.2 & 2.2 & 3.8 & 4.0 & 2.0 & $\overline{1.1}$ & 2.0 \\
\hline \multirow[t]{3}{*}{ SCOL } & Ia & 86.4 & 86.1 & 87.1 & 86.1 & 83.3 & 3.8 & 83.5 & 80.6 & 86.0 & 81.1 & 82.7 & 86.3 & 5.4 & 5.1 \\
\hline & $\mathrm{Ch}$ & 1.5 & 0.0 & 1.6 & 0.0 & 0.0 & 1.6 & 0.0 & 0.0 & 0.0 & 0.0 & 0.0 & 0.0 & $\overline{0.0}$ & 0.0 \\
\hline & $\mathrm{Dp}$ & 12.1 & 13.9 & 11.3 & 13.9 & 16.7 & 5.4 & 16.5 & 19.4 & 14.0 & 18.9 & 17.3 & 13.7 & 5.4 & 5.1 \\
\hline \multirow[t]{5}{*}{ GROW } & $\mathrm{Cr}$ & 56.1 & 59.5 & 53.2 & 55.7 & 65.5 & 12.3 & 67.0 & 67.7 & 64.5 & 67.9 & 64.0 & 78.4 & $\overline{3.2}$ & 14.4 \\
\hline & $\mathrm{Cp}$ & 2.3 & 1.3 & 2.4 & 2.5 & 3.6 & 2.3 & 2.8 & 3.2 & 3.2 & 5.7 & 2.7 & 2.0 & 0.0 & 3.7 \\
\hline & $\mathrm{Sq}$ & 2.3 & 2.5 & 2.4 & 0.0 & 3.6 & 3.6 & 0.0 & 0.0 & 0.0 & 0.0 & 0.0 & 0.0 & 0.0 & 0.0 \\
\hline & Fo & 15.9 & 20.3 & 16.9 & 16.5 & 14.3 & 6.0 & 26.6 & 25.8 & 28.0 & 26.4 & 29.3 & 13.7 & 2.2 & 15.6 \\
\hline & $\mathrm{Fr}$ & 23.5 & 16.5 & 25.0 & 25.3 & 13.1 & 12.2 & 3.7 & 3.2 & 4.3 & 0.0 & 4.0 & 5.9 & 1.1 & 5.9 \\
\hline TCON & $\mathrm{Co}$ & 83.3 & 79.7 & 82.3 & 84.8 & 78.6 & 6.2 & 78.0 & 82.3 & 79.6 & 79.2 & 77.3 & 78.4 & 2.7 & 1.9 \\
\hline & Ds & 1.5 & 2.5 & 1.6 & 0.0 & 2.4 & 2.5 & 5.5 & 6.5 & 4.3 & 9.4 & 5.3 & 2.0 & $\overline{2.2}$ & 7.5 \\
\hline & De & 15.2 & 17.7 & 16.1 & 15.2 & 19.0 & 3.9 & 16.5 & 11.3 & 16.1 & 11.3 & 17.3 & 19.6 & 4.8 & $\overline{8.3}$ \\
\hline PHOT & $\mathrm{Ch}$ & 90.2 & 89.9 & 89.5 & 93.7 & 92.9 & 4.2 & 100.0 & 100.0 & 100.0 & 100.0 & 100.0 & 100.0 & 0.0 & $\overline{0.0}$ \\
\hline & $\operatorname{Tr}$ & 0.8 & 1.3 & 0.8 & 1.3 & 1.2 & 0.5 & 0.0 & 0.0 & 0.0 & 0.0 & 0.0 & 0.0 & 0.0 & 0.0 \\
\hline & Cy & 9.1 & 8.9 & 9.7 & 5.1 & 6.0 & 4.6 & 0.0 & 0.0 & 0.0 & 0.0 & 0.0 & 0.0 & 0.0 & 0.0 \\
\hline TCOL & $\mathrm{Pa}$ & 22.0 & 20.3 & 19.4 & 22.8 & 28.6 & 9.2 & 28.4 & 19.4 & 30.1 & 22.6 & 28.0 & 31.4 & 10.8 & 8.7 \\
\hline & $\mathrm{Gr}$ & 35.6 & 40.5 & 36.3 & 36.7 & 34.5 & 6.0 & 33.9 & 41.9 & 31.2 & 34.0 & 36.0 & 37.3 & $\overline{10.8}$ & 3.3 \\
\hline & $\mathrm{Bb}$ & 18.9 & 20.3 & 20.2 & 12.7 & 16.7 & 7.6 & 20.2 & 16.1 & 23.7 & 13.2 & 24.0 & 23.5 & 7.5 & 10.8 \\
\hline & Oy & 6.1 & 8.9 & 5.6 & 8.9 & 6.0 & 3.2 & 7.3 & 6.5 & 7.5 & 9.4 & 6.7 & 5.9 & 1.1 & 3.6 \\
\hline & Gn & 17.4 & 10.1 & 18.5 & 19.0 & 14.3 & 8.9 & 10.1 & 16.1 & 7.5 & 20.8 & 5.3 & 2.0 & 8.6 & $1 \overline{8.8}$ \\
\hline PRUI & $\mathrm{Ye}$ & 12.9 & 10.1 & 13.7 & 12.7 & 16.7 & 6.5 & 27.5 & 33.9 & 25.8 & 35.8 & 25.3 & 15.7 & 8.1 & $\overline{20.2}$ \\
\hline & $\mathrm{Yn}$ & 4.5 & 6.3 & 4.8 & 5.1 & 3.6 & 2.8 & 1.8 & 1.6 & 2.2 & 0.0 & 2.7 & 2.0 & 0.5 & 2.7 \\
\hline & No & 82.6 & 83.5 & 81.5 & 82.3 & 79.8 & 3.8 & 70.6 & 64.5 & 72.0 & 64.2 & 72.0 & 82.4 & 7.5 & $1 \overline{8.2}$ \\
\hline ACOL & B1 & 35.6 & 38.0 & 33.1 & 39.2 & 47.6 & 14.6 & 56.9 & 53.2 & 59.1 & 43.4 & 58.7 & 72.5 & 5.9 & 29.2 \\
\hline & $\mathrm{Br}$ & 46.2 & 46.8 & 48.4 & 41.8 & 34.5 & 13.9 & 29.4 & 32.3 & 29.0 & 32.1 & 29.3 & 19.6 & 3.2 & 12.5 \\
\hline & $\mathrm{Ot}$ & 18.2 & 15.2 & 18.5 & 19.0 & 17.9 & 3.8 & 13.8 & 14.5 & 11.8 & 24.5 & 12.0 & 7.8 & 2.7 & 16.7 \\
\hline Alip & Yes & 8.3 & 3.8 & 8.9 & 7.6 & 10.7 & 6.9 & 6.4 & 9.7 & 7.5 & 11.3 & 8.0 & 13.7 & 2.2 & 5.7 \\
\hline & $\mathrm{Y} / \mathrm{N}$ & 1.5 & 1.3 & 1.6 & 1.3 & 1.2 & 0.4 & 0.0 & 0.0 & 0.0 & 0.0 & 0.0 & 0.0 & 0.0 & $\overline{0.0}$ \\
\hline Quin & Yes & 4.5 & 5.1 & 4.0 & 5.1 & 4.8 & 1.0 & 8.3 & 9.7 & 5.4 & 13.2 & 6.7 & 2.0 & 4.3 & 11.2 \\
\hline & $\mathrm{Y} / \mathrm{N}$ & 0.8 & 1.3 & 0.8 & 0.0 & 0.0 & 1.3 & 0.0 & 0.0 & 0.0 & 0.0 & 0.0 & 0.0 & 0.0 & $\overline{0.0}$ \\
\hline Chro & Yes & 3.8 & 3.8 & 4.0 & 3.8 & 4.8 & 0.2 & 3.7 & 1.6 & 4.3 & 3.8 & 2.7 & 5.9 & 2.7 & 3.2 \\
\hline & $\mathrm{Y} / \mathrm{N}$ & 0.8 & 1.3 & 0.8 & 0.0 & 1.2 & 1.3 & 0.0 & 0.0 & 0.0 & 0.0 & 0.0 & 0.0 & 0.0 & 0.0 \\
\hline Pulv & Yes & 3.0 & 5.1 & 3.2 & 5.1 & 4.8 & 1.8 & 3.7 & 3.2 & 4.3 & 5.7 & 4.0 & 3.9 & 1.1 & 1.7 \\
\hline & $\mathrm{Y} / \mathrm{N}$ & 4.8 & 2.5 & 1.6 & 2.5 & 2.4 & 0.9 & 0.9 & 1.6 & 0.0 & 0.0 & 1.3 & 0.0 & 1.6 & $\overline{1.3}$ \\
\hline Deps & Yes & 35.6 & 36.7 & 36.3 & 34.2 & 31.0 & 5.8 & 29.4 & 25.8 & 31.2 & 20.8 & 30.7 & 33.3 & 5.4 & 2.7 \\
\hline & $\mathrm{Y} / \mathrm{N}$ & 6.8 & 7.6 & 6.5 & 10.1 & 4.8 & 5.4 & 3.7 & 4.8 & 4.3 & 3.8 & 5.3 & 5.9 & 0.5 & 2.1 \\
\hline Dops & Yes & 27.3 & 24.1 & 24.2 & 34.2 & 27.4 & 10.1 & 29.4 & 37.1 & 30.1 & 35.8 & 30.7 & 21.6 & 7.0 & $1 \overline{4.3}$ \\
\hline & $\mathrm{Y} / \mathrm{N}$ & 11.4 & 11.4 & 11.3 & 11.4 & 13.1 & 1.8 & 14.7 & 17.7 & 14.0 & 11.3 & 16.0 & 21.6 & 3.8 & $\overline{10.2}$ \\
\hline
\end{tabular}


Table 5 continued

\begin{tabular}{|c|c|c|c|c|c|c|c|c|c|c|c|c|c|c|c|}
\hline \multirow{2}{*}{$\begin{array}{l}\text { Functional } \\
\text { traits }\end{array}$} & \multirow{2}{*}{$\begin{array}{l}\text { Functional } \\
\text { attributes }\end{array}$} & \multicolumn{6}{|l|}{ World } & \multicolumn{8}{|c|}{ Regional } \\
\hline & & Overall & Gr. I & Gr. II & Gr. III & Gr. IV & $\begin{array}{l}\Delta \mathrm{Gr} . \\
(\max )\end{array}$ & Overall & $\mathrm{U}$ & $\mathrm{NU}$ & 1.alt. & m.alt. & h.alt. & $\Delta U-N U$ & $\begin{array}{l}\Delta \text { alt. } \\
(\max )\end{array}$ \\
\hline \multirow[t]{2}{*}{ Dibe } & Yes & 8.3 & 2.5 & 8.9 & 7.6 & 9.5 & 7.0 & 4.6 & 6.5 & 5.4 & 9.4 & 5.3 & 3.9 & 1.1 & 5.5 \\
\hline & $\mathrm{Y} / \mathrm{N}$ & 1.5 & 2.5 & 1.6 & 2.5 & 0.0 & 2.5 & 0.0 & 0.0 & 0.0 & 0.0 & 0.0 & 0.0 & 0.0 & $\overline{0.0}$ \\
\hline \multirow[t]{2}{*}{ Terp } & Yes & 7.6 & 7.6 & 8.1 & 5.1 & 9.5 & 4.5 & 7.3 & 4.8 & 8.6 & 7.5 & 8.0 & 9.8 & 3.8 & 2.3 \\
\hline & $\mathrm{Y} / \mathrm{N}$ & 3.8 & 1.3 & 4.0 & 2.5 & 1.2 & 2.8 & 0.0 & 0.0 & 0.0 & 0.0 & 0.0 & 0.0 & $\overline{0.0}$ & 0.0 \\
\hline
\end{tabular}

0.010; ATYP 1.58, 0.040). The number of spore septa (SSEP, $F$ value $1.85, P$ value 0.020 ), the number of spores per ascus (SNUM, $F$ value 1.76, $P$ value 0.018 ) and the production of depsidones (Dops, $F$ value $1.72, P$ value 0.022 ) related to axes 2 (13.8\% of correlation), $3(7.8 \%)$ and $4(7.6 \%)$, respectively, and also showed significant conditional effects. Plots from areas at different altitudes scattered separately along the first axis, independent of the substrate. Plots from high altitudes were positively related with Deps, Alip and ATYP, whereas those of low altitudes were positively correlated with PRUI and, subordinately, GROW, which did not show a significant conditional effect.

\section{Discussion}

Lichen diversity in ultramafic areas

The number of lichen species worldwide is estimated to be about 25,000-28,000 taxa, but there are less than 15,000 described species (Zedda and Rambold 2015; Scheidegger 2016). Our literature survey shows that more than $5 \%$ of these species have been reported on rocks and soils of ultramafic areas, which represent less than $1 \%$ of the land surface of Earth (Brooks 1987). Such species percentage may be even higher when considering the many lichenologically unexplored ultramafic areas (as suggested by works in progress in South Africa, Sri Lanka, Portugal, Massachusetts; see ESM7), and that the listed diversity consists of saxicolous and terricolous (s.1.) taxa only directly related to the substrate, while the reported worldwide lichen diversity also includes a wide epiphytic component. Even if we had updated calculations for the overall saxicolous and terricolous lichens, the relevance of lichen diversity in ultramafic areas may not be comparatively evaluated due to the absence of other world- or continental-scale checklists based on substrate lithology.

The pool of species most frequently reported on ultramafic substrates $(4 \%$ in more than 10 areas) includes common, widely-distributed species often reported from silicate-rocks and related soils worldwide (see Wirth 1972). By contrast, the majority of species, which drive the overall diversity, were only reported from one or two areas. SDR analysis showed low similarity $(\mathrm{S}=10.5)$ across ultramafic areas, which, to- gether with a high replacement $(\mathrm{R}=55.5)$, determines a high anti-nestedness $(S+R=66.0)$, generally indicating a zonal species distribution with high species turnover (Podani and Schmera 2011), rather than an azonal distribution driven by the shared substrate. This pattern agrees with the paucity of endemic lichen species reported from ultramafics, in contrast to the high endemism of phanerogamic communities on ultramafics. Only 8 lichen species, 5 of which are known only from their type localities, can be considered serpentine endemics (see ESM8); however, there is potential that these species may be found on other mafic substrates in the future, as has been the case with other previously reported serpentine-endemic lichen species (Wirth 1972).

The classification of the ultramafic areas on the basis of the presence or absence of lichen species generally reflects their distribution in different climate zones, with reference to the updated Koppen-Geiger classification. Climate (rather than the substrate) may be the primary driver of lichen diversity in ultramafic areas. Although phylogeographic studies have only recently started to address biogeographic histories of lichens (Divakar and Crespo 2015), the recognized groups I-IV and the related subgroups mostly reflect traditionally distinguished lichen biogeographical domains and their relationships (Seaward 1977; Galloway 2009): the highly humid climates of western Europe and western N-America (group I), the boreal coniferous zone (group II), and Southern Europe (groups III and IV), with a Oromediterranean element remarkably related to the central Europe lichen vegetation (Nimis 1996), an alpine element, and some relationships with the "Mediterranean" coast of California. A substrate-specificity is well known for saxicolous and terricolous lichens and is displayed by strong divergence between communities on silicate and carbonate substrates (Brodo 1973). However, a similar divergence may not be seen when lichen communities on different silicate substrates are compared, including serpentinites. Adaptive strategies for living on silicate (and not on carbonate) substrates may be sufficient to cope with the serpentinefactors (see sections below).

\section{Lichen functional traits in ultramafic areas}

A series of functional attributes dominate through all the groups (I-IV) of ultramafic areas, but they merely 

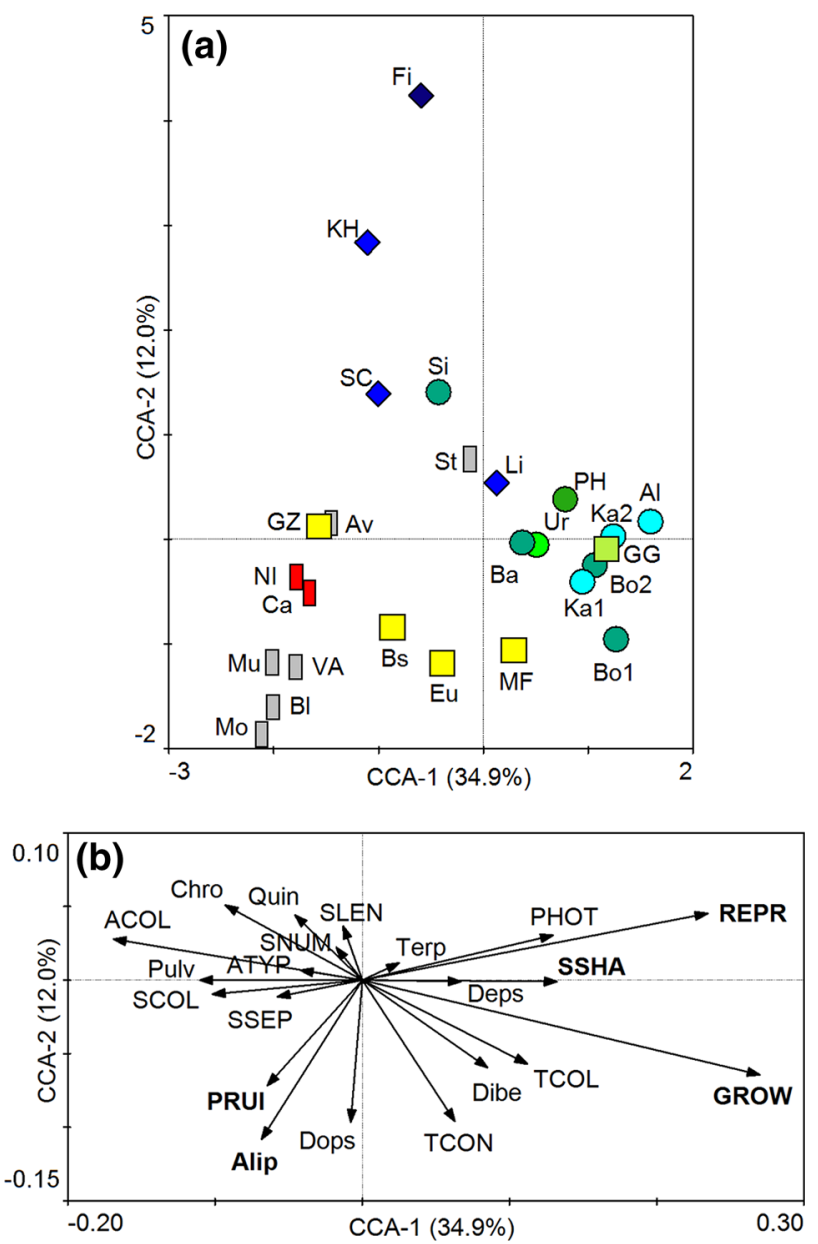

Fig. 4 Factorial maps in the canonical correspondence analysis (CCA-I) showing a the position of ultramafic areas considered at the world scale (abbreviations according to Table 1; symbols according to UPGMA classification in Fig. 2) together with $\mathbf{b}$ the contributions of different functional traits: photosynthetic strategy (PHOT), growth form (GROW), thallus continuity (TCON), color of the thallus (TCOL), occurrence of pruina (PRUI), reproductive strategy (REPR), ascocarp type (ATYP), color of the epithecium/ disc (ACOL), number of ascospores in each ascus (SNUM), spore shape (SSHA), number of septa (SSEP), color (SCOL) and length (SLEN) of the spores, production of secondary metabolites as aliphatic compounds (Alip), quinones (Quin), chromones and xanthones (Chro), pulvinic derivatives (Pulv), depsides (Deps), depsidones (Dops), dibenzofuranes (Dibe), terpenoids (Terp) (functional traits of each species in ESM2). All the extracted axes displayed in the figure were significant according to Monte Carlo test. Functional traits exhibiting significant conditional effects are in bold on the diagram (scores in ESM3)

mirror their dominance in the global lichen biota (e.g. the dominance of chlorococcoid photobionts, crustose species, sexually-reproducing species, asci with 8 simple, ellipsoid, hyaline spores). The more or less noticeable frequency variation of these dominant attributes in favour of other less common attributes (see Table 5) reflects the climate conditions of the different geographic areas and their typical lichen vegetation, independent of the substrate lithology. Highest variations among

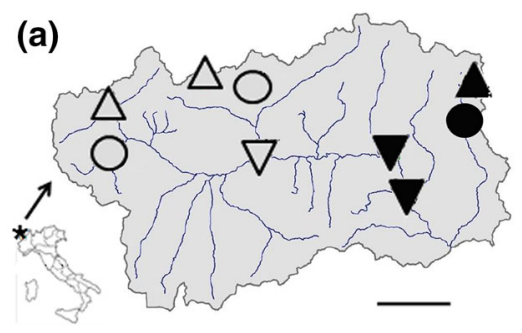

(b)

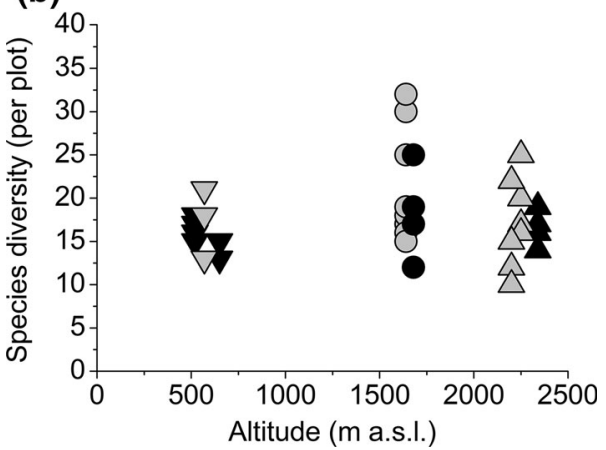

Fig. 5 Lichen richness in ultramafic and non-ultramafic areas of Valle d'Aosta. a Localization of surveyed areas in Valle d'Aosta (NW-Italy, as visualized in the left bottom corner) for ultramafic (black symbols) and non-ultramafic (grey symbols) substrates at low (down triangle), medium (circle) and high (up triangle) altitudes (scale bar $15 \mathrm{~km}$ ); b species diversity per plot in ultramafic and non-ultramafic areas at the different altitudes

groups ( $\Delta$ group max.), recorded for the growth form of thalli, are related to the higher frequency of crustose species in alpine areas, and in the arid areas of California (group IV), than in the more humid areas of the boreal (group II) or Oromediterranean regions of Europe (group III), richer for terricolous fruticose species, while foliose taxa prevail in the oceanic western coasts of Europe (group I) (Seaward 1977). The higher prevalence of sexual reproductive strategies in the alpine areas (group IV) agrees with the prevalence of sexual reproduction in lichens of extreme habitats (Seymour et al. 2005). A higher pigmentation of epithecium (and spores) also characterizes the alpine areas (group IV), playing a protective role against excessive radiation (e.g. Elix and Stocker-Worgotter 2008; Nguyen et al. 2013). Higher occurrence of pruina and aliphatic compounds in species of group IV also agrees with the necessity of alpine lichens to tolerate stresses related to high radiation and low temperatures (e.g. Giordani et al. 2003; Boustie et al. 2011). Accordingly, in CCA-I, functional traits GROW, REPR, PRUI and Alip are significant conditional factors in driving the divergence among lichen communities of ultramafic areas in different climate regimes.

We can thus suggest the occurrence of local trends of adaptation to geographically related environmental pressures more than recognizing common, ultramaficrelated fitness signatures. On the other hand, as in the evaluation of the lichen specific richness through the ultramafic areas, the absence of a similar worldwide 


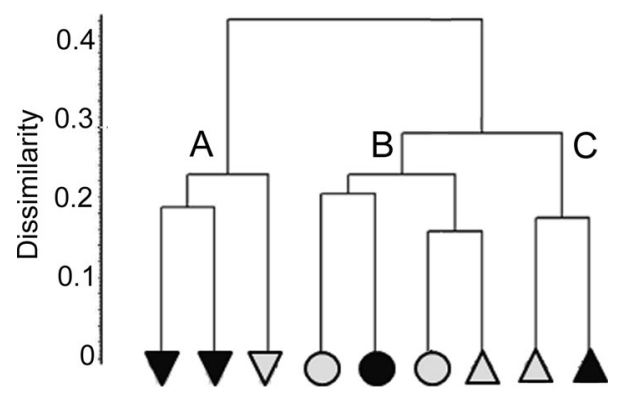

Fig. 6 UPGMA classification of the surveyed ultramafic and nonultramafic areas of Valle d'Aosta on the basis of specific frequency data. Symbols clustered in groups A-C indicate ultramafic (black symbols) and non-ultramafic (grey symbols) areas at low (down triangle), medium (circle) and high (up triangle) altitudes. Cophenetic correlation 0.90

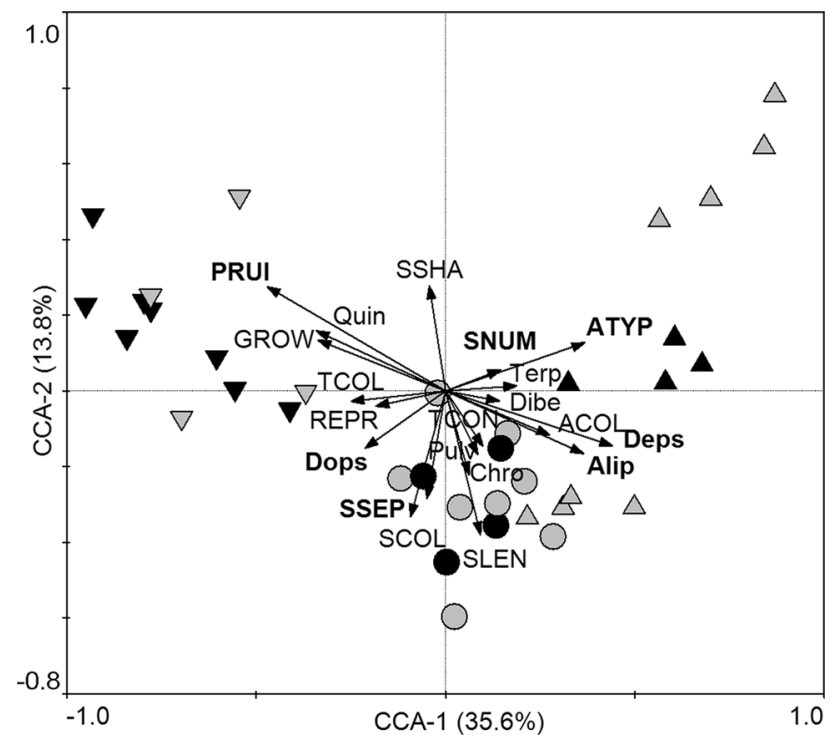

Fig. 7 Factorial maps in the canonical correspondence analysis (CCA-II) showing the position of ultramafic and non-ultramafic areas surveyed at the regional scale of Valle d'Aosta (symbols according to Figs. 5 and 6) together with contributions of the different functional traits (abbreviations as in Fig. 4b): photosynthetic strategy (PHOT), growth form (GROW), thallus continuity (TCON), color of the thallus (TCOL), occurrence of pruina (PRUI), reproductive strategy (REPR), ascocarp type (ATYP), color of the epithecium/disc (ACOL), number of ascospores in each ascus (SNUM), spore shape (SSHA), number of septa (SSEP), color (SCOL) and length (SLEN) of the spores, production of secondary metabolites as aliphatic compounds (Alip), quinones (Quin), chromones and xanthones (Chro), pulvinic derivatives (Pulv), depsides (Deps), depsidones (Dops), dibenzofuranes (Dibe), terpenoids (Terp) (functional traits of each species in ESM5). All the extracted axes displayed in the figure were significant according to Monte Carlo test. Functional traits exhibiting significant conditional effects are in bold on the diagram (scores in ESM6)

survey of functional traits for lichens on non-ultramafic substrates prevents a comparative analysis to recognize shifts of attribute frequencies potentially related to the substrate, which we instead evaluated at the regional level.
Are there peculiarities in lichen communities in ultramafic areas?

The comparative analysis of ultramafic and non-ultramafic areas in the Valle d'Aosta did not show significant paucity of species on ultramafics, in contrast to the paucity of phanerogams commonly reported from ultramafics (Favero-Longo 2014). Dominant species were the same in both ultramafic and non-ultramafic areas, in agreement with their prevalence on silicate (s.l.) areas in Europe and worldwide (see e.g. Wirth 1972). Some species were exclusively recorded in ultramafic or non-ultramafic areas, as previously reported in comparative analysis of serpentine and adjacent mafic outcrops (e.g. Sirois et al. 1987; Paukov and Trapeznikova 2005; Favero-Longo and Piervittori 2009; Paukov 2009; Rajakaruna et al. 2012) and similarity (S) in SDR analysis was slightly higher within ultramafic than in non-ultramafic areas, suggesting the possibility of some substrate-related species distributions. However, the species replacement $(\mathrm{R})$ was the same for ultramafic and non-ultramafic areas, and the lower similarity in nonultramafic areas seems mostly related to differences in diversity richness rather than to peculiar species occurrences. More remarkably, higher similarity and lower species replacement detected at each altitude, independent from the substrate (SDR in Table 4, and UPGMA classification in Fig. 6), suggest that altitude-related climate factors prevail over putative substrate-factors in driving community assemblages at the regional scale. Accordingly, climate-related factors such as water availability and solar radiation were shown to be the dominant drivers of the probability of lichen occurrence at the micro-scale (Giordani et al. 2014).

As expected, functional attributes characterizing the surveyed ultramafic areas in the Valle d'Aosta agree with the trend shown at the world-scale by areas of group IV, including alpine areas: high presence of crustose species, high frequency of sexual reproduction, occurrence of pruina, but also similar patterns of frequency for attributes assigned to thallus continuity/discontinuity and color, and reproductive traits. However, the same (and even higher) agreement was recognized when the surveyed areas were considered altogether and also for the non-ultramafic areas themselves. Moreover, the variation in the frequency of functional attributes was more pronounced between the areas at the different altitudes than between ultramafic and non-ultramafic areas, confirming the primary dependence of lichen assemblages on climate-related factors (varying at different altitudes) than on substrate features. This agrees with the previously reported relationships of lichens with atmospheric-related factors such as humidity (water supply), temperature (dry-wet cycles, metabolic activity), solar radiation (photosynthetic efficiency) (Nash 2008), and a subordinate role of the "substrate compartment", despite its involvement in mineral nutrition (Favero-Longo 2014 with refs therein). 
On the other hand, the fact that saxicolous lichen communities with similar functional attributes colonize all silicate substrates, without any remarkable peculiarity for ultramafic areas, suggests that lichen adaptation to environmental pressures related to silicate rocks also satisfy the tolerance of "serpentine factors", including low nutrient availability and high heavy metal concentrations. Low nutrients, by limiting the phanerogamic component, may be considered a positive factor for lichens, favouring their presence due to lower competition (Favero-Longo and Piervittori 2009). Many studies have considered lichen responses to heavy metals, showing remarkable advances of knowledge with regard to the role of secondary metabolites in modulating $\mathrm{pH}$ and metal homeostasis (Hauck et al. 2009, 2013). For example, variation in the production of secondary metabolites with differential affinity to iron was shown to regulate the presence or absence of certain species on iron-rich substrates (Hauck et al. 2007). Similar metabolic features may be related to the wide-spectrum adaptation of saxicolous lichens to ultramafic and nonultramafic silicate substrates (Favero-Longo et al. 2015), but the analysis of this point goes beyond the aims of this paper and would need direct testing on the contents of secondary metabolites in species (and even thalli) from the surveyed plots (Matteucci et al. 2017). However, on the basis of literature on the specific production of secondary metabolites, the regional survey conducted here shows differences in the frequency of species producing metabolites of different classes (e.g. depsidones) both between ultramafic and non-ultramafic areas and at different altitudes. This finding suggests the need to examine the production of secondary metabolites potentially involved in metal homeostasis not only on different substrates, but also under different climate conditions, which may affect mineral cycling and element availability.

In conclusion, rather than searching for peculiarities in diversity and functional traits, lichenological research may focus on ultramafic environments as natural labs (see Harrison and Rajakaruna 2011) to understand adaptation to metal stresses and the potential role of secondary metabolites in metal homeostasis.

Acknowledgements EM was the recipient of a postdoctoral fellowship (RICERCA FSE 2011-2012, funded by the European Union, Italian Ministry of Labour and Social Policies, Regione Autonoma Valle d'Aosta: agreement 10016/DPLF/28June2012). The authors are grateful to Bianca Bovero (University of Torino) for her assistance during fieldwork and to Rosanna Piervittori (University of Torino) for helpful discussions. The authors thank two reviewers for their useful and constructive comments which helped improve the quality of the manuscript. The work of AP is financially supported by RFBR (Grants 15-04-05971 and 16-04-01346).

\section{References}

Anacker BL (2014) The nature of serpentine endemism. Am J Bot 10:219-224. https://doi.org/10.3732/ajb.1300349
Aptroot A, John V (2015) An historical lichen collection from New Caledonia. Herzogia 28:307-321. https://doi.org/10.13158/heia. 28.2.2015.307

Aptroot A, Van de Vijver B, Lebouvier M, Ertz D (2011) Lichens of Ile Amsterdam and Ile Saint Paul (TAAF, southern Indian Ocean). Nova Hedwigia 92:343-367. https://doi.org/10.1127/ 0029-5035/2011/0092-0343

Armstrong RA (1981) Field experiments on the dispersal, establishment and colonization of lichens on a slate rock surface. Environ Exp Bot 21:115-120. https://doi.org/10.1016/00988472(81)90016-2

Bilovitz PO, Mayrhofer H (2009) A contribution to the lichenized fungi of Bosnia and Herzegovina. Fritschiana (Graz) 65:53-56

Boustie J, Tomasi S, Grube M (2011) Bioactive lichen metabolites: alpine habitats as an untapped source. Phytochem Rev 10:287307. https://doi.org/10.1007/s11101-010-9201-1

Brodo IM (1973) Substrate ecology. In: Ahmadjian V, Hale ME (eds) The lichens. Academic, New York, pp 401-441

Brooks RR (1987) Serpentine and its vegetation: a multidisciplinary approach. Dioscorides Press, Croom Helm

Candan M, Turk AO (2008) Lichens of Malatya, Elazığ and Adiyaman provinces (Turkey). Mycotaxon 105:19-22

Clauzade G, Roux C (1985) Likenoj de Okcidenta Europo. Ilustrita determinlibro. Bull Soc Bot Centre-Ouest 7:3-893

Consortium of North American Lichen Herbaria (CNALH) (2017) http://lichenportal.org/portal/. Accessed 9 Sept 2017

Deduke C, Halden NM, Piercey-Normore MD (2016) Comparing element composition of rock substratum with lichen communities and the fecundity of Arctoparmelia and Xanthoparmelia species. Botany 94:41-51. https://doi.org/10.1139/cjb-2015-0141

Divakar PK, Crespo A (2015) Molecular phylogenetic and phylogenomic approaches in studies of lichen systematics and evolution. In: Upreti DK, Divakar PK, Shukla V, Bajpai R (eds) Recent advances in lichenology. Modern methods and approaches in lichen systematics and culture techniques, vol 2. Springer, New Delhi, pp 45-60

Elix JA, Stocker-Worgotter E (2008) Biochemistry and secondary metabolites. In: Nash TH III (ed) Lichen biology. Cambridge University Press, Cambridge, pp 104-133

Favero-Longo SE (2014) Lichens on metal-rich substrates. In: Rajakaruna N, Boyd R, Harris T (eds) Plant ecology and evolution in harsh environments. Nova Publishers, New York, pp 53-76

Favero-Longo SE, Piervittori R (2009) Measuring the biodiversity of saxicolous lichens above timberline with reference to environmental factors: the case-study of a Natura 2000 site of western Alps. Phytocoenologia 39:51-78. https://doi.org/ 10.1127/0340-269X/2009/0039-0051

Favero-Longo SE, Isocrono D, Piervittori R (2004) Lichens and ultramafic rocks: a review. Lichenologist 36:391-404. https://doi.org/10.1017/S0024282904014215

Favero-Longo SE, Siniscalco C, Piervittori R (2006) Plant and lichen colonization in an asbestos mine: spontaneous bioattenuation limits air dispersion of fibres. Plant Biosyst 140:190-205. https://doi.org/10.1080/11263500600756546

Favero-Longo SE, Matteucci E, Morando M, Rolfo F, Harris T, Piervittori R (2015) Metals and secondary metabolites in saxicolous lichen communities on ultramafic and non-ultramafic rocks of the Western Italian Alps. Austral J Bot 63:276-291. https://doi.org/10.1071/BT14256

Fryday AM (2005) The genus Porpidia in northern and western Europe, with special emphasis on collections from the British Isles. Lichenologist 37:1-35. https://doi.org/10.1017/S00 24282904014628

Gallo LM, Piervittori R (1991) La flora lichenica rupicola dei Monti Pelati di Baldissero (Canavese, Piemonte). In: Giachino PM (ed) I Monti Pelati di Baldissero. Importanza paesistica e scientifica. Atti Convegno 1991, pp. 25-31

Galloway DJ (2009) Lichen biogeography. In: Nash TH III (ed) Lichen biology. Cambridge University Press, Cambridge, pp 315-335 
Gilbert OL (1983) The lichens of Rhum. Trans Bot Soc Edinb 44:139-149. https://doi.org/10.1080/03746608308685380

Gilbert OL, James PW (1987) Field meeting on the Lizard Peninsula, Cornwall. Lichenologist 19:319-334. https://doi.org/ 10.1017/S0024282987000288

Giordani P, Modenesi P, Tretiach M (2003) Determinant factors for the formation of the calcium oxalate minerals, weddellite and whewellite, on the surface of foliose lichens. Lichenologist 35:255-270. https://doi.org/10.1016/S0024-2829(03)00028-8

Giordani P, Benesperi R, Rizzi G, Brunialti G (2009) New records for lichen regional floras of Italy. Webbia 64:153-158. https://doi.org/10.1080/00837792.2009.10670855

Giordani P, Brunialti G, Bacaro G, Nascimbene J (2012) Functional traits of epiphytic lichens as potential indicators of environmental conditions in forest ecosystems. Ecol Indic 18:413-420. https://doi.org/10.1016/j.ecolind.2011.12.006

Giordani P, Incerti G, Rizzi G, Rellini I, Nimis PL, Modenesi P (2014) Functional traits of cryptogams in Mediterranean ecosystems are driven by water, light and substrate interactions. J Veg Sci 25:778-792. https://doi.org/10.1111/jvs.12119

Giordani P, Rizzi G, Caselli A, Modenesi P, Malaspina P, Mariotti MG (2016) Fire affects the functional diversity of epilithic lichen communities. Fungal Ecol 20:49-55. https://doi.org/ 10.1016/j.funeco.2015.11.003

Hafellner J (1991) Die Flechtenflora eines hochgelegenen Serpentinitstockes in den Ostalpen (Osterreich, Steiermark). Mitt Naturwiss Vereins Steiermark Graz 121:95-106

Hafellner J (2001) Bemerkenswerte Flechtenfunde in Osterreich. Fritschiana 28:1-30

Hakulinen R (1958) Jakalia Suomen serpentiinikallioilta. Ann Bot Soc Zool-Bot Fenn "Vanamo" 12:143-145

Hansen CJ, Goertzen LR (2012) Psora icterica (Lecanorales, Psoraceae), a new and interesting disjunction from Alabama. Opuscula Philolichenum 11:49-51

Harris TB, Olday FC, Rajakaruna N (2007) Lichens of Pine Hill, a peridotite outcrop in eastern North America. Rhodora 109:430-447. https://doi.org/10.3119/0035-4902(2007)109[430: LOPHAP]2.0.CO;2

Harrison S, Rajakaruna N (2011) Serpentine. The evolution and ecology of a model system. University of California Press, Berkeley

Hauck M, Huneck S, Elix JA, Paul A (2007) Does secondary chemistry enable lichens to grow on iron-rich substrates? Flora 202:471-478. https://doi.org/10.1016/j.flora.2006.08.007

Hauck M, Jurgens S-R, Willenbruch K, Huneck S, Leuschner C (2009) Dissociation and metal-binding characteristics of yellow substances suggest a relationships with site preferences of lichens. Ann Bot 103:13-22. https://doi.org/10.1093/aob/mcn202

Hauck M, Boning J, Jacob M, Dittrich S, Feussner I, Leuschner C (2013) Lichen substance concentrations in the lichen Hypogymnia physodes are correlated with heavy metal concentrations in the substratum. Environ Exp Bot 85:58-63. https://doi.org/10.1016/j.envexpbot.2012.08.011

Huneck S, Yoshimura I (1996) Identification of lichen substances. Springer, Berlin

Index Fungorum (2017) http://www.indexfungorum.org/. Accessed 9 Sept 2017

Isocrono D, Favero Longo SE, Piervittori R (2008) La flora lichenica del Parco Naturale del Mont Avic (Valle d'Aosta, Italia). Rev Valdôtaine Hist Nat 62:77-93

Kantvilas G (1991) Records of east African lichens in cool temperate Australia. Nordic J Bot 11:369-373. https://doi.org/ 10.1111/j.1756-1051.1991.tb01416.x

Kocakaya M, Halici MG, Aksoy A (2014) Lichenized and lichenicolous fungi of Gevne Valley (Konya, Antalya). Turk J Bot 38:358-369. https://doi.org/10.3906/bot-1303-29

Kossowska M (2001) Epilithic lichens on serpentinite rocks in Poland. Pol Bot J 46:191-197

Kottek M, Grieser J, Beck C, Rudolf B, Rubel F (2006) World map of the Koppen-Geiger climate classification updated. Meteorol Z 15:259-263. https://doi.org/10.1127/0941-2948/2006/0130
Krause W, Klement O (1958) Zur Kenntnis der Flora und Vegetation auf Serpentinstandorten des Balkans. 3. FelsflechtenGesellschaften im Gosrovic-Gebiet (Bosnien) und ZlatiborGebirge (Serbien). Vegetatio 8:1-19

Krause W, Klement O (1962) Zur Kenntnis der Flora und Vegetation aus Sepentinstandorten des Balkans. 5. Flechten und Flechtengesellschaften auf Nord-Euboa (Geiechenland). Nova Hedwigia 4:189-262

Kretschmer L (1931) Die Pflanzengesellschaften auf Serpentin im Gurhofgraben bei Melk. Verh Zool-Bot Ges Wien 80:163-208

Krzewicka B (2009) The 'Verrucaria fuscella group' in Poland with some nomenclatorial remarks. Acta Soc Bot Poloniae 78:229234. https://doi.org/10.5586/asbp.2009.029

Lammermayr L (1934) Uberinstimmung und Unterschiede in der Pflanzendecke uber Serpentin und Magnesit. Mitteilungen der Naturwissenschaftlichen Vereins fur Steiermark, Graz 71:41-62

Malpas J (1992) Serpentine and the geology of serpentinized rocks. In: Roberts A, Proctor J (eds) The ecology of areas with serpentinized rocks. A world view. Kluwer Academic Publishers, Dordrecht, pp 7-30

Matteucci E, Bovero B, Vanacore Falco I, Piervittori R (2015) Comunità licheniche rupicole in Valle d'Aosta: confronti a quote differenti. Rev Valdôtaine Hist Nat 69:61-77

Matteucci E, Occhipinti A, Piervittori R, Maffei ME, FaveroLongo SE (2017) Morphological, secondary metabolite and ITS (rDNA) variability within usnic acid-containing lichen thalli of Xanthoparmelia explored at the local scale of rock outcrop in W-Alps. Chem Biodivers 14:e1600483. https://doi.org/10.1002/ cbdv.201600483

Medeiros ID, Fryday AM, Rajakaruna N (2014) Additional lichen records and mineralogical data from metal-contaminated sites in Maine. Rhodora 116:323-347. https://doi.org/10.3119/13-26

Morando M, Favero-Longo SE, Carrer M, Matteucci E, Nascimbene J, Sandrone S, Appolonia L, Piervittori R (2017) Dispersal patterns of meiospores shape population spatial structure of saxicolous lichens. Lichenologist 49:397-413. https://doi.org/ $10.1017 / \mathrm{S} 0024282917000184$

Nash TH III (2008) Lichen biology. Cambridge University Press, Cambridge

Nelson PR, McCune B, Roland C, Stehn S (2015) Non-parametric methods reveal non-linear functional trait variation of lichens along environmental and fire age gradients. J Veg Sci 26:848865. https://doi.org/10.1111/jvs.12286

Nguyen KH, Chollet-Krugler M, Gouault N, Tomasi S (2013) UVprotectant metabolites from lichens and their symbiotic partners. Nat Prod Rep 30:1490-1508. https://doi.org/10.1039/ C3NP70064J

Nimis PL (1996) Towards a checklist of Mediterranean lichens. Bocconea 6:5-17

Nimis PL (2016) The lichens of Italy. A second annotated catalogue. EUT, Trieste

O'Dell RE, Rajakaruna N (2011) Intraspecific variation, adaptation, and evolution. In: Harrison S, Rajakaruna N (eds) Serpentine. The evolution and ecology of a model system. University of California Press, Berkeley, pp 97-137

Palmqvist K (2000) Tansley review no. 117: carbon economy in lichens. New Phytol 148:11-36. https://doi.org/10.1046/ j.1469-8137.2000.00732.x

Paukov AG (2009). The lichen flora of serpentine outcrops in the Middle Urals of Russia. N E Nat 16 (Special Issue No. 5):341350

Paukov AG, Trapeznikova SN (2005) Lithophilous lichens of Middle Urals. Folia Cryptog Estonica 41:81-88

Paukov A, Sipman HJM, Kukwa M, Repin R, Teptina A (2017) New lichen records from the mountains Kinabalu and Tambuyukon (Kinabalu Park, Malaysian Borneo). Herzogia $30: 237-252$

Peksa O (2011) Lišejnıky narodnı přrıdnı pamatky Křrı̌ky. Sbornık muzea Karlovarskeho kraje 19:259-272

Pichi-Sermolli R (1948) Flora e vegetazione delle serpentine e delle altre ofioliti dell'alta valle del Tevere (Toscana). Webbia 6:1380. https://doi.org/10.1080/00837792.1948.10669585 
Podani J (2001) SYN-TAX 2000. Computer programs for data analysis in ecology and systematics. User's Manual. Scientia Publishing, Budapest

Podani J, Schmera D (2011) A new conceptual and methodological framework for exploring and explaining pattern in presenceabsence data. Oikos 120:1625-1638. https://doi.org/10.1111/ j.1600-0706.2011.19451.x

Poelt J (1975) Squamarina serpentinii species nova (Lichenes, Lecanoraceae) aus Serbien. Herzogia 3:425-432

Purvis OW, Halls C (1996) A review of lichens in metal-enriched environments. Lichenologist 28:571-601. https://doi.org/ 10.1006/lich.1996.0052

Rajakaruna N (2017) Lessons on evolution from the study of edaphic specialization. Bot Rev. https://doi.org/10.1007/ s12229-017-9193-2

Rajakaruna N, Knudsen K, Fryday AM, O'Dell RE, Pope N, Olday FC, Woolhouse S (2012) Investigation of the importance of rock chemistry for saxicolous lichen communities of the New Idria serpentinite mass, San Benito County, California, USA. Lichenologist 44:695-714. https://doi.org/10.1017/S00 24282912000205

Ritter-Studnička H, Klement O (1968) Uber Flechtenarten und deren Gesellschaften auf Serpentin in Bosnien. Oesterr Bot Z 115:93-99

Rubel F, Brugger K, Haslinger K, Auer I (2017) The climate of the European Alps: shift of very high resolution Koppen-Geiger climate zones 1800-2100. Meteorol Z 26:115-125. https://doi. org $/ 10.1127 / \mathrm{metz} / 2016 / 0816$

Ryan BD (1988) Marine and maritime lichens on serpentine rocks on Fidalgo Island, Washington. Bryologist 91:186-190. https://doi.org/10.2307/3243217

Sambo E (1927) I licheni del Monte Ferrato (Toscana). Nuovo Giornale Botanico Italiano 34:333-358

Sambo E (1937) Sull'azione vicariante del magnesio invece del calcio in licheni calcicoli di roccia alcalica. Nuovo Giorn Bot Ital 24:246-250. https://doi.org/10.1080/11263503709437956

Sanchez-Biezma MJ, Lopez de Silanes ME (1999) Porpidia nadvornikiana, a species of ultrabasic rocks: second record for Europe. Lichenologist 31:637-639. https://doi.org/ 10.1006/lich.1999.0238

Sanchez-Biezma Serrano MJ, Alvarez Andres J, de Silanes Lopez, Vazquez ME (2001) Liquenes de las rocas ultamaficas en la Sierra de A Capelada (A Coruña, NW de España). Bot Complut 25:261-269

Sanchez-Biezma MJ, Carballal R, Lopez de Silanes ME (1996) Algunos liquenes de rocas basicas y ultrabasicas nuevos para el nord de España. Cryptogamie Bryologie Lichenologie 17:203211

Scheidegger C (2016) As thick as three in a bed. Mol Ecol 25:32613263. https://doi.org/10.1111/mec.13710/full

Seaward MRD (1977) Lichen ecology. Academic, London
Seymour FA, Crittenden PD, Dyer PS (2005) Sex in the extremes: lichen-forming fungi. Mycologist 19:51-58. https://doi.org/ 10.1017/S0269-915X(05)00201-6

Sigal LL (1989) The lichens of serpentine rocks and soils in California. Mycotaxon 34:221-238

Sipman HJM (1993) Lichens from Mount Kinabalu. Trop Bryol $8: 281-314$

Sirois L, Lutzoni F, Grandtner MM (1987) Les lichens sur serpentine et anphibolite du plateau du mont Albert, Gaspesie, Quebec. Can J Bot 66:851-862. https://doi.org/10.1139/b88-124

Smith CW, Aptroot A, Coppins BJ, Fletcher A, Gilbert OL, James PW, Wolseley PA (2009) The lichens of Great Britain and Ireland. British Lichen Society, London

Suza J (1927) Lichenologicky raz zapadočeskych serpentinů. Čas Morav Zemsk Mus 25:251-281

Takala K, Seaward MRD (1978) Lichens of the Niinivaara serpentinite region, E. Finland. Memoranda Soc Fauna Fl Fenn 54:59-63

Ter Braak CJF, Šmilauer P (2002) CANOCO reference manual and CanoDraw for Windows User's guide:software for canonical community ordination (version 4.5). Microcomputer Power, Ithaca

Ter Braak CJ, Verdonschot PF (1995) Canonical correspondence analysis and related multivariate methods in aquatic ecology. Aquat Sci 57:255-289. https://doi.org/10.1007/BF00877430

van der Ent A, Baker AJ, Reeves RD, Pollard AJ, Schat H (2013) Hyperaccumulators of metal and metalloid trace elements: facts and fiction. Plant Soil 362:319-334. https://doi.org/10.1007/ s11104-012-1287-3

Verseghy K (1974) Nachtrag II. zum "TypenVerzeichnis der Flechtensammlung in der Botanischen Abteilung des Ungarischen Naturwissenschaftlichen Museums". Stud Bot Hung 9:23-29

Vězda A (1972) Haplocarpon nadvornikianum Vězda sp. nov. Preslia 44:208-212

Violle C, Navas ML, Vile D, Kazakou E, Fortunel C, Hummel I, Garnier E (2007) Let the concept of trait be functional! Oikos 116:882-892. https://doi.org/10.1111/j.0030-1299.2007.15559.x

von Brackel W (2007) Zur Flechtenflora der Serpentinitfelsen in Nordostbayern. Hoppea 68:253-268

Wirth V (1972) Die Silikatflechten Gemainschaften im ausseralpinen Zentraleuropa. Diss Bot 17:1-306

Wirth V (1995) Die Flechten. Baden-Wurttembergs. Ulmer, Stuttgart

Zahlbruckner A (1907) Aufzalung der von Dr. H. Bretzl in Griechenland gesammelten Flechten. Hedwigia 47:60-65

Zedda L, Rambold G (2015) The diversity of lichenised fungi: Ecosystem functions and ecosystem services. In: Upreti DK, Divakar PK, Shukla V, Bajpai R (eds) Recent advances in lichenology. Modern methods and approaches in lichen systematics and culture techniques, vol 2. Springer, New Delhi, pp 121-145 